\title{
FACTORS CAUSING REWORK AND THEIR IMPACT ON PROJECTS' PERFORMANCE IN EGYPT
}

\author{
Assim Muwafaq AL-JANABI 10 1, ${ }^{\star}$, Mohamed Shawky ABDEL-MONEM ${ }^{2}$, \\ Karim Mohamed EL-DASH ${ }^{2}$ \\ ${ }^{1}$ Ministry of Planning, Baghdad, Iraq \\ ${ }^{2}$ Department of Civil Engineering at Shoubra, Benha University, Egypt
}

Received 16 February 2019; accepted 20 February 2020

\begin{abstract}
The Egyptian construction industry suffers from severe delays and cost overruns. Rework is a prime cause of this challenge. Therefore, the objective of this study to identify the root causes of rework for Egyptian construction projects and their impact on the project duration and cost. An extensive literature review has been done to identify the most common factors affecting rework. Hence, eighty-seven factors were identified and categorised into ten groups. Structured interview technique was adopted to get the opinions of 67 Egyptian construct professionals for nineteen different construction projects. Total Importance Index of Rework Impact (T.I.I.R.I\%) was used to analyse and rank rework factors. Accordingly, the most critical five rework factors are economic situation for the country, schedule compression, design changes, specifications change, and inadequate feasibility study. Based on the survey results, the project stakeholders should consider the critical rework factors during the planning stage and before the project execution, to eliminate or reduce the occurrence and impact of rework causes and to improve the performance of the projects. This paper provides state of the art for rework causes and their effects on construction projects performance, and it can be beneficial for both practitioners and researchers for future work.
\end{abstract}

Keywords: construction industry, rework, project, performance, cost, time.

\section{Introduction}

The construction industry plays a significant role in national development and is considered one of the most active sectors in the Egyptian economy, accounting for $15 \%$ of GDP (Gross Domestic Product) with high investment reaching US\$21bn (UKTI Digital, 2016). Egypt's average GDP from construction has been calculated as 23,047.06 EGP Million from the period 2007 to 2018, and reaching the highest amount of 59,846.30 EGP Million recorded in the fourth quarter of 2018, according to statistics from the Ministry of Planning (Trading Economics, 2019). Egypt's construction market recorded a $10 \%$ growth in 2017 , compared to a global annual growth rate of $5.3 \%$ over the past four years (Investigate, 2017). In spite of the importance of this industry in Egypt and its active growth during the last years, this industry is still fraught with many risks, known as 'rework', which no construction project can avoid.

Rework is the process of restoring non-conformance characteristics to an acceptable condition, including the items still incompatible to the original requirements (Love, 2002b). Aiyetan (2013) defined rework as a process of modifying the product according to the customer or engineer specifications when the product or service provided does not meet the customer's requirements. Rework is known to contribute to waste and value losses in building design and construction (Kakitahi et al., 2013), and it has been considered as one of the key factors responsible for cost and schedule overruns in construction projects (Shibnai \& Salah, 2015; Love et al., 2010; Hwang et al., 2009; Aiyetan, 2013; Love \& Li, 2000). According to the study by Kakitahi et al. (2016), the impact of rework on project cost and schedule has been calculated to be approximately $4.53 \%$ and $8.42 \%$, respectively. Josephson et al. (2002) carried out a case study survey and reported that the cost of rework was $4.4 \%$ of the construction value, and the time spent on reworking was $7.1 \%$ of the total work time. Also, rework is the main reason for lower prof-

This article was originally published with error. This version has been amended. Please see Corrigendum https://doi.org/10.3846/jcem.2021.14331

*Corresponding author. E-mail: assimmuwafaq@gmail.com

Copyright (c) 2020 The Author(s). Published by Vilnius Tech Press

This is an Open Access article distributed under the terms of the Creative Commons Attribution License (http://creativecommons.org/licenses/by/4.0/), which permits unrestricted use, distribution, and reproduction in any medium, provided the original author and source are credited. 
it, claims, and dissatisfaction of the owner and contractor (Eze \& Idiake, 2018; Wasfy, 2010).

On the other hand, rework can lead to labour and productivity losses. Thomas and Napolitan (1995) explained that the daily loss in labour productivity could range from $25 \%$ to $50 \%$ due to the required changes, and attributed the principal reason for these disruptions to the absence of the materials needed to enable the rework to be undertaken. In Egypt, for example, Shibnai and Salah (2015) have mentioned that rework is the main reason for time and cost overrun, and it is considered to be one of the most critical factors that affect labour productivity in Egyptian construction projects (Gerges, 2015).

Many construction professionals acknowledge that rework is a significant factor contributing to the poor performance of construction projects (Love \& Edwards, 2004). Therefore, the root causes of rework should be identified before becomes a critical management issues (Hwang et al., 2009; Fayek et al., 2003; Ye et al., 2014). Accordingly, it several research efforts have been expended in this area to identify the causes of rework and their impact on performance of both cost and time of project for different construction sectors and countries (e.g. Hwang et al., 2009; Josephson et al., 2002; Li \& Taylor, 2014; Love \& Edwards, 2005; Mahamid, 2016; Palaneeswaran, 2006; Love \& Li, 2000; Simpeh, 2012; Enshassi et al., 2017; Miri \& Khaksefidi, 2015; Kakitahi et al., 2016; Jarkas, 2015). However, rework is still a critical global phenomenon in the construction industry. Love and Smith (2018) stated there had been limited progress made to reduce its occurrence and adverse consequences due to several studies that have identified individual causal factors instead of acknowledging the interdependency and complicated relationships that contribute to rework (Love \& Smith, 2018). Besides, Ye et al. (2014) mentioned that little is known about rework causes in developing countries.

Indeed, rework can be mitigated and enhanced by identifying and managing its common root causes. So to achieve this, the research study objectives have been summarised as follows:

- Identify and understand the factors that cause rework in the Egyptian construction industry.

- Measure the impact of rework on the cost and time of construction projects in Egypt.

- Conduct a comparative study of the most critical rework causes in a current study and the results of previous studies or other countries.

- Increase the awareness of the project stakeholders about the risk of rework and devise suitable measures of rework management and reduction.

\section{Literature review}

\subsection{Rework definition}

Rework as a verb means to revise or work again (Love \& Smith, 2018). In the construction context, a lot of the rework definitions have been promulgated in the litera- ture. For example, Ashford (1992) defined rework as a process in which an item should conform to the original requirements by the correction or completion, or as a correction for at least or more extra than once due to nonconformance to requirements (McDonald, 2013). On the other hand, the terms of "non-conformance" and "quality failure" have been used to infer to the rework (AbdulRahman, 1995; Barber et al., 2000). Likewise, Burati et al. (1992) have named it a "quality deviation" which ultimately refers to 'repair' or 'replacement'.

However, Love et al. (2000) defined rework as an unnecessary effort of re-doing a process or activity which incorrectly completed for the first time. In general, Construction Industry Institute [CII] (2001) described rework as "Activities in a field that must perform more than once, or activities which remove the works that previously installed in the field as part of the project". Besides, Fayek et al. (2003) described it as a total direct cost for re-doing work in the field regardless of what was the initiating source.

Rework is a significant factor that has a negative impact (direct and indirect) on the performance for both of the project or organisation and leads to reduced productivity, lower profits, extra costs and time, and client's dissatisfaction (Love, 2002a, 2002b). Additionally, rework has been defined rework as a waste of the time and cost of doing specific tasks again, which cannot be eliminated but maybe avoid (Oyewobi et al., 2011).

\subsection{Rework causes}

Rework can mainly result from four primary sources, which are, error, omission, change, and damage during design and construction processes, as concluded by Love and Li (2000, adapted from Burati et al., 1992). Besides, Palaneeswaran (2006) indicated that rework also arises from failures, changes, poor coordination, and poor communication. Many previous studies have been conducted to identify the factors causing rework in the construction industry for different countries. In Australia, for example, Love et al. (2010) examined 42 factors to determine the root causes and consequential costs of rework in civil infrastructure projects, based on the data collected from 115 civil infrastructure projects. The results of their research indicated that the five significant rework causes are ineffective use of information technologies, excessive client involvement in the project, lack of clearly defined working procedures, changes made at the request of the client, and insufficient changes initiated by the contractor to improve quality, which accounted for $25 \%$ of the variance in total rework cost. Also, Love et al. (2009) studied divergence or congruence of rework for 260 building and civil engineering projects. They identified 29 causes of the rework. Their findings concluded that the changes directed by the client, site management and subcontractors, and project communication were significant contributors to rework costs.

Based on a survey, Jarkas (2015) identified 36 causes of the rework of building projects in Qatar and grouped 
them into four categories related to the client, designer, contractor, and exogenous. According to his findings, he concluded that frequent changes during the construction stage, obscure contractual clauses and specifications, incomplete design details at the tendering stage, errors and omissions in design drawings, and shortage in skilled labour were the five fundamental rework causes.

In Palestine, Enshassi et al. (2017) studied the reasons for the rework construction industry in the Gaza Strip. They concluded that 57 reasons accounted for construction rework and grouped them into seven categories, namely, those related to the contractor, human resource capability, design, external environment, client, materials and equipment supply, and construction process. Their findings indicated that the main rework factors are the attempts of fraud by the contractor, competitive pressure (low contract value), ineffective management, schedule pressure, and the absence of job security. According to another study, Mahamid (2016) identified 43 causes of rework in residential building projects in the West Bank and grouped them into four categories, namely, those related to the client, contractor, consultant, and environment. The results of this study indicated that poor communication of the client with the consultant, the poor communication of the client with the contractor, use of poor quality materials, poor site management, and poor communication of the client with the design consultant are the top five causes and the most severe.

In their study, Ye et al. (2014) conducted a survey to identify the causes of rework in construction projects in China. The survey identified 39 causes of rework that have been categorised into 11 major groups. According to their findings, the lack of clarity of the project management process, poor quality of the construction technology, and the use of poor-quality materials were the most important causes of rework.

Eze et al. (2018a) studied the causes of rework in the construction industry in Nigeria. They identified 47 causes of rework and grouped them into four major categories. Their findings indicate that contractor and design-related causes are the most important categories for rework triggers. According to their study, the most common causes of rework were unclear instructions to workers, shortage of skill, and incomplete and inaccurate information. Beside, Ajayi and Oyeyipo (2015) examined the causes and effects of rework in Nigerian building projects. Accordingly, they concluded that poor communication with the design consultant, the use of poor quality materials, and low-skilled workers are the chief causes of reworks.

Hwang et al. (2014) examined client-related rework in building projects in Singapore based on data collected from 51 construction companies. They identified 7 clientrelated factors as causes of rework. Their findings concluded that the change of plans or scope by the client is the greatest contributor and impacts the cost, schedule, and quality of performance of the project. As a separate study, Hwang et al. (2016) have evaluated the rework factors in green building construction projects in Singapore. They concluded that the owner change, design change, design error/omission, and contractor's error/omission were the four most critical factors of rework in green building construction projects.

In India, Raghuram and Nagavinothini (2016) studied the causes and impact of rework in the construction project. They identified 40 causes of rework and grouped them into five categories, which are related to client, design, construction, site, and sub-contractor. According to their findings, the lack of experience and knowledge of the design and construction process, incomplete drawings, errors due to inappropriate construction methods, shortage of skilled labours, and inadequate supervision are the significant causes of the rework.

In Malaysia, Yap et al. (2017) surveyed the impact and causes of rework in building construction projects. They identified 18 causes of rework and grouped them into five categories, namely: 1) project coordination management; 2) technology, machines, and material management; 3 ) project implementation management; 4) design process management; 5) site workmanship management. Their findings concluded that poor coordination among the design team was the most common cause of rework.

It is worth mentioning that most of the previous studies mainly investigated certain categories of rework causes, and they were for particular sectors, such as the buildings and infrastructures for the different countries. Hence, little is known about the nature of rework causation. So, there has been limited progress made in reducing rework occurrence and containing its adverse consequences. Accordingly, it becomes necessary to determine as possible as the most extensive number of rework causes in various construction sectors, as well as measuring their impact on the cost and time performances for the project.

Based on the 24 previous studies, a total of 87 factors of rework have been identified and listed in the related ten groups, as summarised in Appendix, Table A1. The table shows the number of rework factors studied by each reference, their frequency, and the percentage of each group of all rework causes. Based on this summary, hence, the results indicated that among the most frequent rework factors were incomplete design at the time of the tender, poor communication of client with the contractor/design consultant, insufficient labour skills, the lack of sufficient client knowledge and experience in the design and construction process, and weak of quality considerations by contractor and subcontractor.

\subsection{Rework impact on project performance}

The rework is a significant factor contributing to poor project performance and requiring the number of design and production management strategies to reduce it (Love et al., 2009). The rework has adverse consequences on project performance, which cause time delays and cost overruns for any project, according to several prior studies (i.e. Dahanayake \& Ramachandra, 2016; Yap et al., 
2016; Hwang et al., 2009; Fayek et al., 2004). Additionally, rework causes many claims between the project parties, lower profits, lack of staff's incentives, as well as the design team dissatisfaction, removal of motivation for workers, thus losing future work (Eze \& Idiake, 2018).

In general, the rework cost includes both direct and indirect costs. Love (2002b) mentioned that the indirect costs of rework are the costs cannot be allocated to monetary value, which occurs at individual levels, such as (fatigue and stress), and organisation level, such as the (lowing of profits, conflicts, and loss of future work), and project level such as (inactivity and end-users dissatisfaction). Notwithstanding, the indirect costs caused by rework may reach three to six times the direct (actual) costs of the actual work (Love, 2002b). However, direct and indirect costs of rework have been calculated by Love (2002a), as $6.4 \%$ and $5.6 \%$ of the original contract value, respectively. Actually, direct costs alone often calculate, as accounted for $5 \%$ of the total construction costs as appointed by Hwang et al. (2009).

Several studies have revealed the cost of rework in the construction industry; for example, the total cost of rework in infrastructure projects has been estimated to about $10 \%$ of the contract value (Love et al., 2010). Mahamid (2016) indicated the average cost of rework in residential projects ranging from $10 \%$ to $15 \%$. For highway projects, Abdul-Rahman (1995) found that the cost of non-conformance (cost of rework) represented 5\% from contract value and which not include material wastage and head office overheads.

Most of the researchers are agreed that the rework leads to the cost overruns and schedule delays, depending on project type and region. In Australia, for example, average cost overrun and schedule delays have been calculated as $12.6 \%$ and $20.7 \%$ respectively of 116 samples taken from construction projects (Love, 2002a). Additionally, Wasfy (2010) find out that the rework increases in the cost as $2-30 \%$ and schedule delay as $10-70 \%$ for different work categories, for a residential and commercial project in Saudi Arabia. Also, Abeku et al. (2016) estimated that the rework causes cost overrun by $12.58 \%$ and time overrun by $38 \%$ for selected one construction project in Nigeria. Accordingly, this research will first identify the main causes of rework for construction projects in Egypt. Rank all factors based on their index value under each category. Then, compare the current study results with other countries' reworks factors.

\section{Research method}

Currently, no research efforts have been undertaken in Egypt to identify the causes of the rework and their impact on the performance of construction projects. Consequently, this study will utilise the quantitative survey to investigate and evaluate common causes of rework and their impact on project performance, based on opinions of construction experts and practitioners in the Egyptian construction industry.

\section{Literature review}

A literature investigation was carried out to identify factors that cause the rework and its impact in the construction industry

Rework Factors selection

- The field interviews with experts were carried out as pre-analysis to modified and removed the similarity of rework factors

- The factors of rework were categorized into ten groups-related distinct

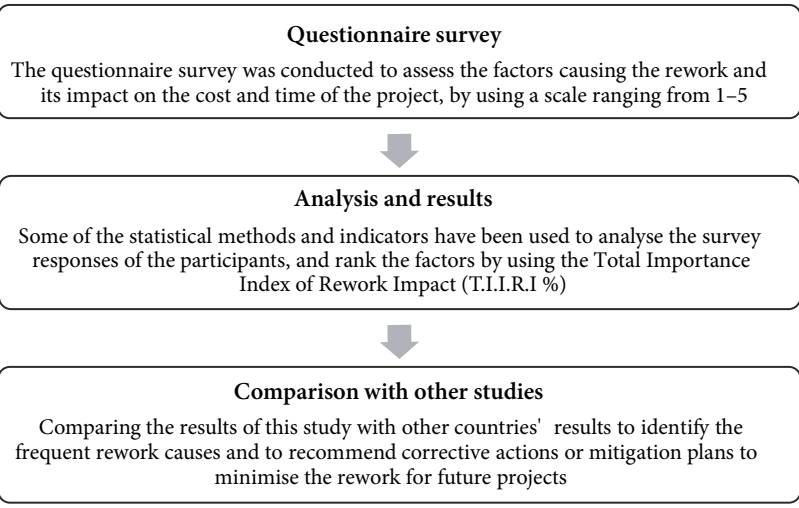

Figure 1. The research method

For achieving the objectives of this study, the research methodology is designed to include five consecutive steps, as shown in Figure 1. First, an extensive literature review has been done to determine rework causes and their impact on project performance. A total of 87 factors of rework causes were identified and categorised into ten groups related to client, design, contractor and subcontractor, contract, construction, supervision, material and equipment, site, external, and labour, as indicated in Table 1. Consequently, the initial questionnaire has been developed to be composed of two main parts. The first part is including the demographic information about respondents.

The second part regards the factors that cause construction rework. For each rework factor, the respondents will answer three questions: the first question about the frequency of occurrence of rework factor, the second question about the severity impact of rework factor on project cost, and the third question about the severity impact of rework factor on project duration. A five-point scale was used to categorise the answers for the three questions, which are 1 - very low; 2 - low; 3 - medium; 4 - high; and 5 - very high.

To determine the suitability of the questionnaire to achieve the desired purpose of the study, a pilot survey was conducted to see if the questions are clear, provide an opportunity to improve the questionnaire, demystify it, and omit the redundant factors (Fellows \& Liu, 2008; Eze et al., 2018b; Enshassi et al., 2010, 2017). Accordingly, the field survey for five projects was selected, and the face-toface interviews were conducted with four project managers, five technical office managers, and three consulting office managers, whose experience exceeds 15 years to ben- 
efit from their experiences and points view to help review the causes of rework and the format of the questionnaire, which these pre-identified. Furthermore, the final questionnaire was adjusted based on their recommendations. Nineteen projects from different construction sectors in Cairo, all of which suffered from reworking problems, have been selected as a sample size for this study. These projects are ranged from large to mega projects, with contract value from 45 million to 5.25 billion EGP ( $\$ 1 \cong 16.5$ EGP). The average completion rate for these projects was more than $80 \%$. Sixteen out of nineteen were new projects (89.47\%), including five residential buildings, three roads, one bridge, one underground metro station, one industry building, one automatic multi-story car parking, one bank, one hospital, and two commercial buildings. The three other projects were renovation projects $(10.53 \%)$, two hospitals, and one archaeological building, as illustrated in Table 2. The final questionnaire has been distributed to 100 participants representing different types of projects, which are construction professionals, such as consultants, site engineers, site managers, quality engineers, planning engineers, project managers, supervisors, technical office engineers, and technical office managers. A total of 67 questionnaires was received. Although the number of respondents was relatively small, it matches most of the previous studies (e.g. Assaf \& Al-Hejji, 2006; Liao \& Teo, 2017; Durdyev et al., 2017; Rachid et al., 2019; Gamil \& Abdul Rahman, 2020).

The respondents have been classified into four categories depending on the type of organisation, experiences, job position, and projects that belong to them. Figure 2 illustrates the number of participants and years of experience for the surveyed projects. Additionally, Table $3 \mathrm{dem}$ onstrates in detail the organisation type, the job position, and projects that they belong to. It is shown that contractors represent 50.7\%, consultants, $40.3 \%$, and owners (client), $9 \%$, which is low because, in most cases, consultants represent the clients. Besides, most participant jobs in the survey were consultants, technical office engineers, and project managers, at $34.4 \%, 14.9 \%$, and $13.4 \%$, respectively.
Table 2. Description of the sample size projects

\begin{tabular}{|l|c|c|c|}
\hline \multicolumn{1}{|c|}{ Project type } & $\begin{array}{c}\text { No. of } \\
\text { project }\end{array}$ & $\begin{array}{c}\text { Contract value } \\
\text { (EGP) }\end{array}$ & $\begin{array}{c}\text { Project } \\
\text { description }\end{array}$ \\
\hline $\begin{array}{l}\text { Residential } \\
\text { building }\end{array}$ & 5 & $\begin{array}{c}250 \text { million } \\
\text { to } 2.20 \text { billion }\end{array}$ & new \\
\hline Road and bridge & 3 & $\begin{array}{c}406 \text { million } \\
\text { to } 5.25 \text { billion }\end{array}$ & new \\
\hline $\begin{array}{l}\text { Underground } \\
\text { metro station }\end{array}$ & 1 & 2.21 billion & new \\
\hline Industry building & 1 & 1 billion & new \\
\hline $\begin{array}{l}\text { Automatic multi- } \\
\text { storey car parking }\end{array}$ & 1 & 249 million & new \\
\hline Bank & 1 & 600 million & new \\
\hline Hospital & 1 & 2.35 billion & new \\
\cline { 2 - 5 } & 2 & 65 and 500 million & renovation \\
\hline $\begin{array}{l}\text { Commercial } \\
\text { building }\end{array}$ & 2 & 45 and 300 million & new \\
\hline Hotel & 1 & 120 million & renovation \\
\hline $\begin{array}{l}\text { Archaeological } \\
\text { building }\end{array}$ & 1 & 70 million & renovation \\
\hline Total & 19 & & \\
\hline
\end{tabular}

Respondents' ratio for residential projects was 27 out of a total of 67 , which represents $40.3 \%$ since the current trend in the Egyptian construction industry towards residential projects for both the private and the public sectors.

After data collection is complete, data reliability or relevance was verified by using Cronbach's alpha $(\alpha)$ reliability testing as a measure of internal consistency (Tavakol \& Dennick, 2011; Rachid et al., 2019). Statistical Package for the Social Sciences (SPSS V22) program was used to measure the alpha coefficient for the frequency of occurrence of rework factor, the severity impact of rework factor on the project cost, and the severity impact of rework factor on the time for all 87 rework factors, which were $\alpha=0.981,0.976$ and 0.980 , respectively. This result is more than 0.7 as designated limit value, showing strength in the internal consistency for data (Xin \& Rong, 2007; Tavakol \& Dennick, 2011; Gamil \& Abdul Rahman, 2020).

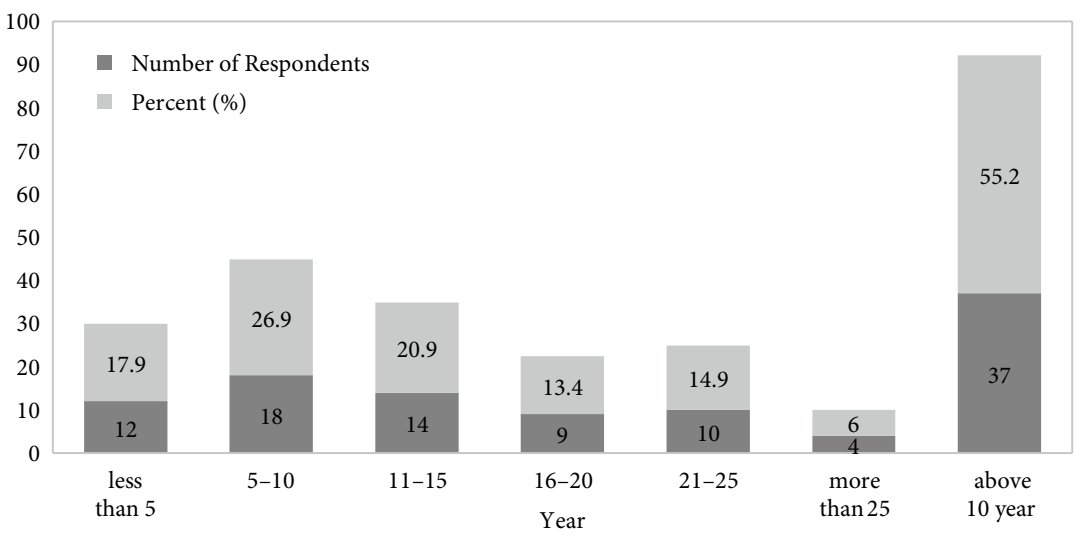

Figure 2. Number of participants and years of experience for the surveyed projects 
Table 3. Respondents' statistics summary

\begin{tabular}{|c|c|c|}
\hline Organisation & $\begin{array}{l}\text { Number of } \\
\text { respondents }\end{array}$ & $\begin{array}{l}\text { Percent } \\
(\%)\end{array}$ \\
\hline Consultant & 27 & 40.3 \\
\hline Contractor & 34 & 50.7 \\
\hline Owner & 6 & 9.0 \\
\hline Total & 67 & 100.0 \\
\hline Job position & $\begin{array}{l}\text { Number of } \\
\text { respondents }\end{array}$ & Percent (\%) \\
\hline Consultant & 23 & 34.3 \\
\hline Implementation engineer & 11 & 16.4 \\
\hline Implementation manager & 2 & 3.0 \\
\hline Monitor quality & 2 & 3.0 \\
\hline Planning engineer & 1 & 1.5 \\
\hline Planning manager & 1 & 1.5 \\
\hline Project manager & 9 & 13.4 \\
\hline Supervisor & 2 & 3.0 \\
\hline Technical office engineer & 10 & 14.9 \\
\hline Technical office manager & 6 & 9.0 \\
\hline Total & 67 & 100.0 \\
\hline Project type & $\begin{array}{l}\text { Number of } \\
\text { respondents }\end{array}$ & Percent (\%) \\
\hline Archaeological building & 3 & 4.5 \\
\hline Bank & 4 & 6.0 \\
\hline Commercial building & 5 & 7.5 \\
\hline Hospital & 5 & 7.5 \\
\hline Hotels & 1 & 1.5 \\
\hline Industry building & 2 & 3.0 \\
\hline Parking & 2 & 3.0 \\
\hline Residential building & 27 & 40.3 \\
\hline Road and bridge & 14 & 20.9 \\
\hline Underground metro station & 3 & 4.5 \\
\hline Water station & 1 & 1.5 \\
\hline Total & 67 & 100.0 \\
\hline
\end{tabular}

\section{Data analysis}

All of 67 respondents' data collected have been analysed by using four major statistical indicators, which are frequency, severity, importance, total importance. These indicators are fundamental to prioritise rework causes for each category and to identify the most critical factors that have high frequency and high impact on both time and cost of the project. The following Eqns from (1) to (4) illustrate the formula of each indicator adopted in this study, as shown.

Frequency Index: is a formula to calculate the frequency of occurrence for rework causes as identified by participants and can be calculated according to Eqn (1) (Assaf \& Al-Hejji, 2006; Bekr, 2015):

$$
\text { Freqency Index }(F . I)(\%)=\sum a(n / N) \star 100 / 5 \text {, }
$$

where: $a$ is a constant expressing the weight given to each response (range from 1 for very low up to 5 very high of the occurrence), $n$ is the frequency of the response, and $N$ is the total number of responses.

Severity Index: is a formula to calculate the severity impact on project cost and project duration according to participants' opinions and can be calculated according to Eqn (2) (Mahamid, 2016; Bekr, 2015; Assaf \& Al-Hejji, 2006):

$$
\text { Severity Index }(S . I)(\%)=\sum a(n / N) \star 100 / 5,
$$

where: $a$ is a constant expressing the weight given to each response (range from 1 for very low up to 5 very high of the severity), $n$ is the frequency of the response, and $N$ is the total number of responses.

Importance Index of Rework Cost and Time Impact (I.I.R.C.I)/(I.I.R.T.I): can be calculated as a function of both frequency and severity indices. This indicator shows the impact of each rework factor on project cost or project duration, as shown in Eqn (3) (Assaf \& Al-Hejji, 2006; Bekr, 2015):

$$
(\text { I.I.R.C.I }) /(\text { I.I.R.T.I })(\%)=[\text { F.I }(\%) * S . I(\%)] / 100 \text {, }
$$

where: F.I $(\%)$ and S.I $(\%)$ represent the frequency and severity indices for the specific rework factor, which were calculated from Eqns (1) and (2).

Total Importance Index of overall Rework Impact (T.I.I.R.I): can be calculated as a function of both importance indices for project cost and time impact and can be calculated as shown in Eqn (4):

$$
\begin{aligned}
& \text { T.I.I.R.I }(\%)= \\
& {\left[W_{1}{ }^{*} \text { I.I.R.C.I }(\%)+W_{2}{ }^{\star} \text { I.I.R.T.I }(\%)\right] / 100,}
\end{aligned}
$$

where: T.I.I.R.I - Total Importance Index of the overall Rework Impact; I.I.R.C.I - Importance Index of Rework Cost Impact, that was calculated from Eqn (3); I.I.R.T.I Importance Index of Rework Time Impact, that was calculated from Eqn (3); $W_{1}, W_{2}$ represent a constant where: $(0 \leq W \leq 1)$, weighted based on participants' opinion. In this study, $W_{1}$ and $W_{2}$ have been assumed to be equal: $W_{1}=W_{2}=0.5$.

\section{Results and discussion}

All received data from 67 respondents have been organised so to arrange the data of total 87 rework factors, according to the category to which they belong. Hence, the frequency index (F.I\%) of each rework factor has been calculated, according to Eqn (1), and severity index (S.I\%) of rework on the cost and time of project has been calculated based on the Eqn (2). Besides, Eqn (3) calculates the importance index of the rework cost impact (I.I.R.C.I\%) and the importance index of rework time impact (I.I.R.T.I\%). Finally, the factors of rework have been ranked based on total importance index of rework impact (T.I.I.R.I\%), which has been calculated by Eqn (4). The discussion of the analysis results of the ten rework factors groups is shown in the following sections below. 


\subsection{Client related factors}

The client is the most influential party in the decisionmaking process within the project. Many previous studies (e.g. Mahamid, 2016; Yap et al., 2017; Forcada et al., 2016; Love et al., 2010; Eze et al., 2018a) have found the client to be one of the primary reasons for construction rework. Hence, the frequent variation orders of the client may be accompanied ultimately by a rework occurrence (Enshassi et al., 2010). The cost of rework that only related to client was estimated at 6\% among total rework costs in Swedish Construction Industry (Josephson et al., 2002), and amounted $7.1 \%$ and $14.73 \%$ as others studies conducted by Hwang et al. (2014) in Singapore and Liu et al. (2020) in residential buildings of China, respectively.

Table 4 illustrates the most dominated factors associated with the client, which included 11 factors that cause the rework in the Egyptian construction market. According to survey results, the notable and most influential factors are: the first was "Specifications change by the client" and ranked position 4th of a total of 87 reworks factors with T.I.I.R.I $=44.41 \%$. This result corresponds to the study by Hwang et al. (2014). The change in specifications by the client during the construction phase may want significant adjustments in project planning and procurement activities (Enshassi et al., 2010; Arain \& Pheng, 2006). So that should be finalised in the initial phase of a project.

Additionally, "Inadequate or weak feasibility study" was ranked second in this group and came in the 5th position of all rework causes with T.I.I.R.I $=44.28 \%$. Subsequently, the improper feasibility study has a negative impact on construction project performance (Long et al., 2004). The third critical factor was "Change of plan or scope" which ranked in the 6th position with T.I.I.R.I $=43.79 \%$, and this contributes to a negative impact on project cost, schedule, and quality performance according to Hwang et al. (2014). Furthermore, Ye et al. (2014) disclosed that the lack of clear project scope in the early stages during the design or construction stages would result in frequent modifications and revisions for project functions.

Finally, "Poor communication with the contractor / design consultant" has been ranked at the least influential factor in the client group in Egypt, and ranked as 74th position among all of the rework factors. This ranked, however, does not correspond to other studies for different countries such as Palestine (Mahamid, 2016), Nigeria (Eze et al., 2018a), which have ranked this factor at first positions with the most influence.

\subsection{Contractor and subcontractor related factors}

Contractor related factors (Ye et al., 2014; Aiyetan, 2013; Eze et al., 2018a; Enshassi et al., 2017) and subcontractor related factors (Ye et al., 2014; Miri \& Khaksefidi, 2015; El Hussein, 2014; Love et al., 2004) are important reasons influencing rework in other countries. Furthermore, Liu et al. (2020) mentioned that the contractor and subcontractor are responsible for $20.10 \%$ and $10.54 \%$ of the total cost of rework in Chinese residential buildings.

This group has a significant impact and including 11 key factors causing rework, as shown in Table 5. According to the expert responses, "Lack of funding and cash flows" was the most critical one in this group and ranked in the 8th position among all rework factors with T.I.I.R.T $=41.54 \%$. This result agrees with the findings of several previous studies (e.g. Aiyetan, 2013; Long et al., 2004; Enshassi et al., 2017) that financial problems of the construction companies or the late payments by the client lead to work pressure and negatively affect the project performance. The second factor was "Inefficient selection of the subcontractor" and ranked as 9th with T.I.I.R.T = $41.21 \%$. This result substantiates the outcomes of Mahamid (2016), Ajayi and Oyeyipo (2015) whose ranked the factor mentioned above as one of the most influencing causes of the rework of construction in Palestine and Nigeria, respectively. Actually, many Egyptian construction projects are suffering from the defects and damage caused

Table 4. Ranking the causes and impact of rework factors related to the client group

\begin{tabular}{|c|c|c|c|c|c|c|c|c|c|}
\hline Code & Factors cause the rework & $\begin{array}{l}F . I \\
(\%)\end{array}$ & $\begin{array}{l}\text { S.I on } \\
\text { cost }(\%)\end{array}$ & $\begin{array}{l}\text { S.I on } \\
\text { time }(\%)\end{array}$ & $\begin{array}{l}\text { I.I.R.C.I } \\
\quad(\%)\end{array}$ & $\begin{array}{l}\text { I.I.R.T.I } \\
\quad(\%)\end{array}$ & $\begin{array}{l}\text { T.I.I.R.I } \\
\quad(\%)\end{array}$ & $\begin{array}{c}\text { Group } \\
\text { rank }\end{array}$ & $\begin{array}{c}\text { Overall } \\
\text { rank }\end{array}$ \\
\hline RF1 & Specifications change by the client & 63.58 & 68.36 & 71.34 & 43.46 & 45.36 & 44.41 & 1 & 4 \\
\hline RF2 & Inadequate or weak feasibility study & 62.99 & 68.96 & 71.64 & 43.43 & 45.12 & 44.28 & 2 & 5 \\
\hline RF3 & Change of plan or scope & 62.69 & 66.87 & 72.84 & 41.92 & 45.66 & 43.79 & 3 & 6 \\
\hline RF4 & $\begin{array}{l}\text { Weak planning of the project as (construction } \\
\text { planning) }\end{array}$ & 61.49 & 65.37 & 69.85 & 40.20 & 42.95 & 41.58 & 4 & 7 \\
\hline RF5 & $\begin{array}{l}\text { Weak communication/coordination with end- } \\
\text { users }\end{array}$ & 61.79 & 62.99 & 67.46 & 38.92 & 41.69 & 40.30 & 5 & 12 \\
\hline RF6 & $\begin{array}{l}\text { Lack of sufficient knowledge and experience } \\
\text { for the design and construction process }\end{array}$ & 57.31 & 61.49 & 68.36 & 35.24 & 39.18 & 37.21 & 6 & 19 \\
\hline RF7 & Weak quality management system & 59.10 & 60.30 & 63.28 & 35.64 & 37.40 & 36.52 & 7 & 22 \\
\hline RF8 & Insufficient client/owner resources & 53.73 & 58.21 & 66.27 & 31.28 & 35.61 & 33.44 & 8 & 33 \\
\hline RF9 & Lack of funding allocated for consultation & 50.15 & 54.93 & 58.21 & 27.54 & 29.19 & 28.37 & 9 & 56 \\
\hline RF10 & Lack of client involvement in the project & 48.96 & 52.84 & 59.40 & 25.87 & 29.08 & 27.47 & 10 & 64 \\
\hline RF11 & $\begin{array}{l}\text { Poor communication with the contractor / } \\
\text { design consultant }\end{array}$ & 46.87 & 50.45 & 55.52 & 23.64 & 26.02 & 24.83 & 11 & 74 \\
\hline
\end{tabular}


by subcontractors. Therefore, the construction experts recommended effective criteria for selecting subcontractors, for example, must have previous experience in construction projects to avoid the negative rework. The third factor was "Insufficient skill and defective workmanship of subcontractor" and ranked in the 20th position with T.I.I.R.T = $36.87 \%$. This result confirms many scholars' findings (e.g. Yap et al., 2017; Ajayi \& Oyeyipo, 2015; Raghuram \& Nagavinothini, 2016; Love \& Edwards, 2004; Simpeh, 2012; El Hussein, 2014; Miri \& Khaksefidi, 2015; Love et al., 2004, 2010).

\subsection{Contract related factors}

The rework usually resulted from poor contract management due to ambiguous and unclear scope in the contract documentation. Ye et al. (2014) attributed the main reason for these to unserious handling for contract management process by stakeholders, the absence of independent departments for contract management, and lack of the pro- fessional contract management staff for the construction companies and clients. Besides, Hassanein and El Nemr (2008) confirmed that the Egyptian construction sector was suffering from poor documentation management, that assigned mainly to a lack of contract awareness by interested parties.

In this group, eight factors caused rework for construction projects in Egypt, as shown in Table 6. According to survey results, the most influential factor was "Unclear/ poor items of contract documentation" and ranked in 34th position among all rework causes with T.I.I.R.I $=33.13 \%$. This result supported by several researchers, such as Ye et al. (2014), Love et al. (2004), and Jarkas (2015). Basically, the ambiguity in the contract documents items leads to misunderstanding and errors of construction activities' implementation, causing claims and the change orders, thus lead to rework. Therefore, the experts recommended proper preparation for the contract documentation and the contract form by a professional team to minimising construction rework.

Table 5. Ranking the rework factors related to the contractor and subcontractor

\begin{tabular}{|c|c|c|c|c|c|c|c|c|c|}
\hline Code & Factors cause the rework & $\begin{array}{l}\text { F.I } \\
(\%)\end{array}$ & $\begin{array}{c}\text { S.I on } \\
\text { cost }(\%)\end{array}$ & $\begin{array}{c}\text { S.I on } \\
\text { time }(\%)\end{array}$ & $\begin{array}{l}\text { I.I.R.C.I } \\
(\%)\end{array}$ & $\begin{array}{l}\text { I.I.R.T.I } \\
(\%)\end{array}$ & $\begin{array}{l}\text { T.I.I.R.I } \\
(\%)\end{array}$ & $\begin{array}{l}\text { Group } \\
\text { rank }\end{array}$ & $\begin{array}{l}\text { Overall } \\
\text { rank }\end{array}$ \\
\hline RF12 & Lack of funding and cash flows & 62.69 & 62.99 & 69.55 & 39.48 & 43.60 & 41.54 & 1 & 8 \\
\hline RF13 & Inefficient selection of the subcontractor & 61.49 & 63.58 & 70.45 & 39.10 & 43.32 & 41.21 & 2 & 9 \\
\hline RF14 & $\begin{array}{l}\text { Insufficient skill and defective } \\
\text { workmanship of subcontractor }\end{array}$ & 57.31 & 62.99 & 65.67 & 36.10 & 37.64 & 36.87 & 3 & 20 \\
\hline RF15 & Weak of quality considerations & 57.31 & 57.61 & 63.28 & 33.02 & 36.27 & 34.64 & 4 & 28 \\
\hline RF16 & $\begin{array}{l}\text { Non-compliance with specifications and } \\
\text { standards }\end{array}$ & 54.63 & 60.00 & 62.69 & 32.78 & 34.24 & 33.51 & 5 & 32 \\
\hline RF17 & $\begin{array}{l}\text { Poor coordination and communication } \\
\text { with consultants, such as designers }\end{array}$ & 53.73 & 55.82 & 63.28 & 29.99 & 34.00 & 32.00 & 6 & 40 \\
\hline RF18 & $\begin{array}{l}\text { Insufficient managerial and supervisory } \\
\text { skills }\end{array}$ & 53.43 & 55.52 & 60.60 & 29.67 & 32.38 & 31.02 & 7 & 44 \\
\hline RF19 & $\begin{array}{l}\text { Poor coordination/communication } \\
\text { between contractor and subcontractor }\end{array}$ & 49.85 & 55.22 & 60.90 & 27.53 & 30.36 & 28.94 & 8 & 54 \\
\hline RF20 & Restrictions for some activities and tasks & 50.45 & 53.73 & 57.91 & 27.11 & 29.21 & 28.16 & 9 & 58 \\
\hline RF21 & Lack of safety considerations in the site & 52.54 & 51.64 & 54.03 & 27.13 & 28.39 & 27.76 & 10 & 61 \\
\hline RF22 & Failure to protect of the constructed works & 48.06 & 49.55 & 52.84 & 23.81 & 25.39 & 24.60 & 11 & 75 \\
\hline
\end{tabular}

Table 6. Ranking the causes and impact of rework factors related to the contract

\begin{tabular}{|c|c|c|c|c|c|c|c|c|c|}
\hline Code & Factors cause the rework & $\begin{array}{l}\text { F.I } \\
(\%)\end{array}$ & $\begin{array}{c}\text { S.I on } \\
\text { cost }(\%)\end{array}$ & $\begin{array}{c}\text { S.I on } \\
\text { time }(\%)\end{array}$ & $\begin{array}{l}\text { I.I.R.C.I } \\
(\%)\end{array}$ & $\begin{array}{l}\text { I.I.R.T.I } \\
(\%)\end{array}$ & $\begin{array}{c}\text { T.I.I.R.I } \\
(\%)\end{array}$ & $\begin{array}{c}\text { Group } \\
\text { rank }\end{array}$ & $\begin{array}{l}\text { Overall } \\
\text { rank }\end{array}$ \\
\hline RF23 & $\begin{array}{l}\text { Unclear/poor items of contract } \\
\text { documentation }\end{array}$ & 55.22 & 59.10 & 60.90 & 32.64 & 33.63 & 33.13 & 1 & 34 \\
\hline RF24 & $\begin{array}{l}\text { Insufficient time required to prepare } \\
\text { contract documentation }\end{array}$ & 55.22 & 54.93 & 57.91 & 30.33 & 31.98 & 31.16 & 2 & 43 \\
\hline RF25 & $\begin{array}{l}\text { Inexperienced staff to prepare contract } \\
\text { documentation }\end{array}$ & 51.05 & 58.21 & 57.61 & 29.71 & 29.41 & 29.56 & 3 & 52 \\
\hline RF26 & Procurement method & 49.85 & 56.12 & 54.93 & 27.98 & 27.38 & 27.68 & 4 & 62 \\
\hline RF27 & Insufficient client brief & 50.15 & 51.05 & 54.33 & 25.60 & 27.24 & 26.42 & 5 & 68 \\
\hline RF28 & $\begin{array}{l}\text { Errors or omissions in the contract } \\
\text { documentation }\end{array}$ & 49.55 & 51.64 & 53.43 & 25.59 & 26.48 & 26.03 & 6 & 71 \\
\hline RF29 & $\begin{array}{l}\text { Lack of funding by the client to prepare } \\
\text { contract documentation }\end{array}$ & 46.57 & 48.66 & 53.43 & 22.66 & 24.88 & 23.77 & 7 & 78 \\
\hline RF30 & Poor implementation of the contract & 44.18 & 53.13 & 49.55 & 23.47 & 21.89 & 22.68 & 8 & 83 \\
\hline
\end{tabular}




\subsection{Design related factors}

The design is an essential part of any construction project and always maybe have accompanied by many omissions, errors, and changes that causing rework during both the design and construction process. Therefore, most of the scholars have pointed out it as one most significant causes for construction rework (e.g. Love et al., 2004; El Hussein, 2014; Feng \& Tommelein, 2009; Enshassi et al., 2017). According to a case study, Josephson et al. (2002) estimated that the rework cost related to the design only as $26 \%$ from all rework costs and represents $18.91 \%$ also for residential buildings (Liu et al., 2020).

This group includes 13 rework causes in the Egyptian construction industry, as shown in Table 7. According to analysis results, "Design change due to its contradiction with the utilities" has been ranked first in this group and 3rd for overall rework factors, with T.I.I.R.I $=47.83 \%$. Supported this result by Burati et al. (1992) and Chang et al. (2011). The Egyptian construction projects, especially infrastructure projects, are suffering from changes or modifications in the design during the construction phase, due to several problems during the construction phase, such as the existence of underground utilities (water, gas pipes, electricity cables). Therefore, contractors are forced to request a partial modification of the design and schemes, causing delays and increasing costs. Also, the second significant factor was "Design change at the client order or end-user" and ranked 11th with T.I.I.R.I $=40.66 \%$. This result chimes the outcomes of the many studies (e.g. Yap et al. 2017; Eze et al., 2018a; Love et al., 2004). While the third factor was "Incomplete design at the time tender" and ranked as 14th position with T.I.I.R.I $=38.07 \%$. This result conforms with several prior studies (e.g. Enshassi et al., 2017; Mahamid, 2016; Love et al., 2010; Jarkas, 2015). In fundamental, one of the most common problems in the Egyptian construction industry is starting project construction by the contractor with incomplete or preliminary designs, causing severe issues during construction. The lack of complete design before tender stage can be related to the insufficient time of the design preparation, or the client's desire to achieve the project as soon as possible.

\subsection{Supervisory related factors}

Table 8 listed the six most important factors related to the supervisory group, which causes rework. According to survey results, the notable factors came were, the first was "Improper planning for the project activities" and ranked 13 th of all rework causes with T.I.I.R.I $=38.36 \%$. This result supported by Alwi et al. (2001). Based on experts' opinions, it was noted that the adequate planning of the supervisors for both construction activities and job positions would be effectively minimised rework at the field. The second important factor was "Inadequate supervision by design consultant" and ranked position 31st with T.I.I.R.I $=38.36 \%$. Noticeably, the appointing of a design consultant as a supervision consultant in construction projects would be ease correspondence with other consultants and to ensure the correctness, the design schemes, consequently, can be substantially minimised the construction's conflicts (Choudhry, 2016).

While the third factor among supervisory related factors was "Lack of supervisory experiences" and ranked po-

Table 7. Ranking the causes and impact of rework factors related to the design group

\begin{tabular}{|c|c|c|c|c|c|c|c|c|c|}
\hline Code & Factors cause the rework & $\begin{array}{l}\text { F.I } \\
(\%)\end{array}$ & $\begin{array}{c}\text { S.I on } \\
\text { cost }(\%)\end{array}$ & $\begin{array}{c}\text { S.I on } \\
\text { time }(\%)\end{array}$ & $\begin{array}{l}\text { I.I.R.C.I } \\
(\%)\end{array}$ & $\begin{array}{l}\text { I.I.R.T.I } \\
\quad(\%)\end{array}$ & $\begin{array}{l}\text { T.I.I.R.I } \\
\quad(\%)\end{array}$ & $\begin{array}{c}\text { Group } \\
\text { rank }\end{array}$ & $\begin{array}{c}\text { Overall } \\
\text { rank }\end{array}$ \\
\hline RF31 & $\begin{array}{l}\text { Design change due to its contradiction with } \\
\text { the utilities }\end{array}$ & 65.67 & 70.15 & 75.52 & 46.07 & 49.60 & 47.83 & 1 & 3 \\
\hline RF32 & $\begin{array}{l}\text { Design change at the client order or end- } \\
\text { user }\end{array}$ & 60.00 & 65.37 & 70.15 & 39.22 & 42.09 & 40.66 & 2 & 11 \\
\hline RF33 & Incomplete design at the time tender & 60.30 & 61.49 & 64.78 & 37.08 & 39.06 & 38.07 & 3 & 14 \\
\hline RF34 & $\begin{array}{l}\text { Errors and omission during the design } \\
\text { process }\end{array}$ & 55.22 & 62.69 & 66.57 & 34.62 & 36.76 & 35.69 & 4 & 25 \\
\hline RF35 & $\begin{array}{l}\text { Design change because of the difficulty of } \\
\text { implementation }\end{array}$ & 56.12 & 61.49 & 65.08 & 34.51 & 36.52 & 35.51 & 5 & 26 \\
\hline RF36 & $\begin{array}{l}\text { Poor coordination and communication } \\
\text { between the design team }\end{array}$ & 54.03 & 61.19 & 59.10 & 33.06 & 31.93 & 32.50 & 6 & 37 \\
\hline RF37 & Unclear of the client's requirements & 53.73 & 57.91 & 59.40 & 31.12 & 31.92 & 31.52 & 7 & 41 \\
\hline RF38 & Poor quality practices & 52.24 & 56.72 & 61.49 & 29.63 & 32.12 & 30.88 & 8 & 46 \\
\hline RF39 & $\begin{array}{l}\text { Insufficient experience of the design } \\
\text { consultants }\end{array}$ & 52.84 & 55.82 & 59.70 & 29.49 & 31.54 & 30.52 & 9 & 48 \\
\hline RF40 & $\begin{array}{l}\text { Misunderstanding of client/end-user } \\
\text { requirements }\end{array}$ & 51.94 & 55.52 & 58.51 & 28.84 & 30.39 & 29.61 & 10 & 51 \\
\hline RF41 & $\begin{array}{l}\text { Non-compliance with specifications and } \\
\text { standards }\end{array}$ & 48.66 & 54.03 & 55.52 & 26.29 & 27.02 & 26.65 & 11 & 67 \\
\hline RF42 & Pay the low fee for design preparation & 46.27 & 53.73 & 48.36 & 24.86 & 22.37 & 23.62 & 12 & 79 \\
\hline RF43 & $\begin{array}{l}\text { Lack of using modern technology and } \\
\text { software }\end{array}$ & 45.97 & 48.06 & 51.05 & 22.09 & 23.47 & 22.78 & 13 & 82 \\
\hline
\end{tabular}


sition 36th with T.I.I.R.I $=32.69 \%$. This result is in line with the concluded findings of Alwi et al. (1991), Ajayi and Oyeyipo (2015), and Mahamid (2016). The functions of supervisors are to use the available resources effectively and efficiently, which depends on experiences and quality of supervision (Alwi et al., 2001). Accordingly, the contractors should spend more money, as training costs, to develop supervisory skills. In this regard, it founds that the contractors who have been regularly conducting training programs can reasonably reduce their rework costs that are ranging between $11 \%$ to $22 \%$ (Alwi et al., 1999).

\subsection{Construction-related factors}

Most changes and modifications through the project life cycle are occurring during the construction phase, whether due to change requests and non-conformance or defects. Hence, various researchers have nominated construction-related factors as a significant rework causes (e.g. Enshassi et al., 2017; Raghuram \& Nagavinothini, 2016; Love et al., 2004; Kakitahi et al., 2016).

This group consists of 11 critical factors of the rework causes, as shown in Table 9, which are ranked according to their impact, as the experts have named. Hence, the most significant and notable factors are: the first was "Schedule compression" and has ranked in the 2nd position among overall factors with T.I.I.R.T $=51.75 \%$. This result further corroborates the outcomes of Enshassi et al. (2017), Ye et al. (2014), and Jarkas (2015) whose recognised that an unrealistic schedule is a significant rework cause. Besides, Ye et al. (2014) illustrated that any schedule readjustment has an unfavourable impact on project performance and attributed this to poor client process management. The second important factor is "Changes initiated by client/ end-user after work has been undertaken" and ranked in the 10 th position with T.I.I.R.T $=41.01 \%$. This result conforms with several studies (i.e. Raghuram \& Nagavinothini, 2016; Ye et al., 2014; Jarkas, 2015; Love et al., 2004, 2010). However, the large numbers of Egyptian construction project managers have complained from late entries of change requests submitted by owners or end-users, which they consider a waste of time and cost, arisings the claims, as well as labourers' stress.

"Inadequate pre-construction planning of the project" was the third influential factor and ranked as 24th among all factors with T.I.I.R.T $=36.00 \%$. This result is in line

Table 8. Ranking the causes and impact of rework factors related to supervisory

\begin{tabular}{|c|c|c|c|c|c|c|c|c|c|}
\hline Code & Factors cause the rework & $\begin{array}{l}\text { F.I } \\
(\%)\end{array}$ & $\begin{array}{c}\text { S.I on } \\
\text { cost }(\%)\end{array}$ & $\begin{array}{c}\text { S.I on } \\
\text { time }(\%)\end{array}$ & $\begin{array}{c}\text { I.I.R.C.I } \\
(\%)\end{array}$ & $\begin{array}{c}\text { I.I.R.T.I } \\
(\%)\end{array}$ & $\begin{array}{c}\text { T.I.I.R.I } \\
(\%)\end{array}$ & $\begin{array}{c}\text { Group } \\
\text { rank }\end{array}$ & $\begin{array}{c}\text { Overall } \\
\text { rank }\end{array}$ \\
\hline RF44 & Improper planning for the project activities & 58.81 & 63.28 & 67.16 & 37.21 & 39.50 & 38.36 & 1 & 13 \\
\hline RF45 & Inadequate supervision by design consultant & 57.61 & 55.82 & 60.90 & 32.16 & 35.08 & 33.62 & 2 & 31 \\
\hline RF46 & Lack of supervisory experiences & 54.63 & 58.51 & 61.19 & 31.96 & 33.43 & 32.69 & 3 & 36 \\
\hline RF47 & Lack of motivational and leadership skills & 54.33 & 54.33 & 57.61 & 29.52 & 31.30 & 30.41 & 4 & 50 \\
\hline RF48 & Inadequate supervision & 51.64 & 51.64 & 57.61 & 26.67 & 29.75 & 28.21 & 5 & 57 \\
\hline RF49 & Misunderstanding of schemas and designs & 49.55 & 51.94 & 53.73 & 25.74 & 26.62 & 26.18 & 6 & 69 \\
\hline
\end{tabular}

Table 9. Ranking the causes and impact of rework factors related to the construction group

\begin{tabular}{|c|c|c|c|c|c|c|c|c|c|}
\hline Code & Factors cause the rework & $\begin{array}{l}F . I \\
(\%)\end{array}$ & $\begin{array}{c}\text { S.I on } \\
\text { cost }(\%)\end{array}$ & $\begin{array}{c}\text { S.I on } \\
\text { time }(\%)\end{array}$ & $\begin{array}{l}\text { I.I.R.C.I } \\
(\%)\end{array}$ & $\begin{array}{l}\text { I.I.R.T.I } \\
\quad(\%)\end{array}$ & $\begin{array}{l}\text { T.I.I.R.I } \\
\text { (\%) }\end{array}$ & $\begin{array}{l}\text { Group } \\
\text { rank }\end{array}$ & $\begin{array}{c}\text { Overall } \\
\text { rank }\end{array}$ \\
\hline RF50 & Schedule compression & 71.94 & 70.75 & 73.13 & 50.89 & 52.61 & 51.75 & 1 & 2 \\
\hline RF51 & $\begin{array}{l}\text { Changes initiated by client/end-user after } \\
\text { work has been undertaken }\end{array}$ & 61.19 & 65.08 & 68.96 & 39.82 & 42.20 & 41.01 & 2 & 10 \\
\hline RF52 & $\begin{array}{l}\text { Inadequate pre-construction planning of the } \\
\text { project }\end{array}$ & 57.02 & 60.00 & 66.27 & 34.21 & 37.78 & 36.00 & 3 & 24 \\
\hline RF53 & $\begin{array}{l}\text { changes due to inappropriate/difficult the } \\
\text { methods of construction in site }\end{array}$ & 55.52 & 59.70 & 64.18 & 33.15 & 35.63 & 34.39 & 4 & 29 \\
\hline RF54 & $\begin{array}{l}\text { Repair of damage caused by the } \\
\text { subcontractor }\end{array}$ & 54.03 & 57.91 & 63.88 & 31.29 & 34.51 & 32.90 & 5 & 35 \\
\hline RF55 & $\begin{array}{l}\text { Changes made at the request by a design } \\
\text { consultant for quality improvement }\end{array}$ & 52.24 & 57.91 & 64.78 & 30.25 & 33.84 & 32.04 & 6 & 39 \\
\hline RF56 & $\begin{array}{l}\text { Changes made at the request by the } \\
\text { contractor to improve quality }\end{array}$ & 53.43 & 56.72 & 60.30 & 30.31 & 32.22 & 31.26 & 7 & 42 \\
\hline RF57 & $\begin{array}{l}\text { Change due to omissions or non- } \\
\text { conformance to the original design }\end{array}$ & 51.64 & 56.12 & 57.91 & 28.98 & 29.91 & 29.44 & 8 & 53 \\
\hline RF58 & $\begin{array}{l}\text { Construction error due to design } \\
\text { misunderstanding }\end{array}$ & 47.76 & 49.25 & 52.84 & 23.52 & 25.24 & 24.38 & 9 & 76 \\
\hline RF59 & $\begin{array}{l}\text { Lack of use proper and modern construction } \\
\text { technology }\end{array}$ & 43.88 & 48.06 & 50.75 & 21.09 & 22.27 & 21.68 & 10 & 85 \\
\hline
\end{tabular}


with findings by Enshassi et al. (2017). Thus, to ensures the smooth and successful implementation of the project during construction phases, the pre-construction phase should be accurately planned to identify possible project risks before they occur on site. Moreover, Al-Reshaid et al. (2005) demonstrated that the pre-construction planning enables project executors from monitoring and control professionally of the two most important aspects of the success of any construction project, are namely cost and time. Therefore, improper planning of these two vital aspects during the pre-construction phase may cause cost overruns and time.

\subsection{Site-related factors}

Site-related factors are among significant factors that causing rework (El Hussein, 2014; Love et al., 2004; Simpeh, 2012; Raghuram \& Nagavinothini, 2016). This category includes eight factors that cause construction rework in Egypt, as shown in Table 10. According to the analysis results, the critical factors in this group are: "Poor site conditions (e.g. soil problems, water, electricity)" is ranked as the first crucial factor in this group and ranked as 18th among all rework causes with T.I.I.R.I $=37.27 \%$. This result consistent with two beforehand studies conducted by Mahamid (2016) and Ye et al. (2014). In Egypt, the poor conditions of the worksite (such as soil structure or high underground water level and unknown location for underground unities) represent hidden risks which lead to many changes in the construction method or design and thus increase the project cost and duration.

The second factor is "Lack of client funding for the site investigation" has been ranked 23rd with T.I.I.R.I = $36.46 \%$. This result is corroborating to several prior studies ' findings (e.g. Mahamid, 2016; Eze et al., 2018a; Love et al., 2010). In fact, many of Egyptian construction projects are suffering from a lack of funding by the client/ contractor to investigate site conditions in which turn to reduce the rework impact during the construction phase.

\subsection{Labours related factors}

Table 11 illustrated the major ten rework causes related to the labour group. According to the survey results, the

Table 10. Ranking the causes and impact of rework factors related to the site

\begin{tabular}{|c|c|c|c|c|c|c|c|c|c|}
\hline Code & Factors cause the rework & $\begin{array}{l}\text { F.I } \\
(\%)\end{array}$ & $\begin{array}{c}\text { S.I on } \\
\text { cost }(\%)\end{array}$ & $\begin{array}{c}\text { S.I on } \\
\text { time }(\%)\end{array}$ & $\begin{array}{l}\text { I.I.R.C.I } \\
(\%)\end{array}$ & $\begin{array}{l}\text { I.I.R.T.I } \\
(\%)\end{array}$ & $\begin{array}{l}\text { T.I.I.R.I } \\
\quad(\%)\end{array}$ & $\begin{array}{c}\text { Group } \\
\text { rank }\end{array}$ & $\begin{array}{c}\text { Overall } \\
\text { rank }\end{array}$ \\
\hline RF60 & $\begin{array}{l}\text { Poor site conditions (e.g., soil problems, } \\
\text { water, electricity) }\end{array}$ & 56.12 & 64.18 & 68.66 & 36.02 & 38.53 & 37.27 & 1 & 18 \\
\hline RF61 & $\begin{array}{l}\text { Lack of client funding for the site } \\
\text { investigation }\end{array}$ & 57.61 & 59.40 & 67.16 & 34.22 & 38.69 & 36.46 & 2 & 23 \\
\hline RF62 & $\begin{array}{l}\text { Poor management and resource planning in } \\
\text { the site }\end{array}$ & 54.33 & 54.03 & 59.70 & 29.35 & 32.43 & 30.89 & 3 & 45 \\
\hline RF63 & Lack of safety and job security & 53.43 & 50.45 & 52.24 & 26.96 & 27.91 & 27.43 & 4 & 65 \\
\hline RF64 & $\begin{array}{l}\text { Bad site practices and site status that is } \\
\text { overlooked by the contractor }\end{array}$ & 50.15 & 51.94 & 52.24 & 26.05 & 26.20 & 26.12 & 5 & 70 \\
\hline RF65 & $\begin{array}{l}\text { Lack of support for site management by the } \\
\text { contractor }\end{array}$ & 45.97 & 47.76 & 51.94 & 21.96 & 23.88 & 22.92 & 6 & 81 \\
\hline RF66 & $\begin{array}{l}\text { Delay providing the site requirements for } \\
\text { the contractor by a client, such as water, } \\
\text { electricity }\end{array}$ & 47.16 & 44.18 & 49.55 & 20.84 & 23.37 & 22.10 & 7 & 84 \\
\hline RF67 & Failure/Inaccurate the site's investigations & 44.18 & 47.463 & 45.97 & 20.97 & 20.31 & 20.64 & 8 & 87 \\
\hline
\end{tabular}

Table 11. Ranking the causes and impact of rework factors related to the labours

\begin{tabular}{|c|c|c|c|c|c|c|c|c|c|}
\hline Code & Factors cause the rework & $\begin{array}{l}F . I \\
(\%)\end{array}$ & $\begin{array}{c}S . I \text { on } \\
\text { cost }(\%)\end{array}$ & $\begin{array}{l}\text { S.I on } \\
\text { time }(\%)\end{array}$ & $\begin{array}{c}\text { I.I.R.C.I } \\
(\%)\end{array}$ & $\begin{array}{l}\text { I.I.R.T.I } \\
\quad(\%)\end{array}$ & $\begin{array}{c}\text { T.I.I.R.I } \\
(\%)\end{array}$ & $\begin{array}{c}\text { Group } \\
\text { rank }\end{array}$ & $\begin{array}{l}\text { Overall } \\
\text { rank }\end{array}$ \\
\hline RF68 & $\begin{array}{l}\text { Shortage of skilled labours required to complete } \\
\text { work tasks }\end{array}$ & 60.00 & 58.81 & 67.46 & 35.28 & 40.48 & 37.88 & 1 & 15 \\
\hline RF69 & Poor workmanship & 56.72 & 61.49 & 67.76 & 34.88 & 38.43 & 36.65 & 2 & 21 \\
\hline RF70 & Reallocation /turnover of the staff to another site & 60.60 & 54.03 & 62.99 & 32.74 & 38.17 & 35.45 & 3 & 27 \\
\hline RF71 & Insufficient training to develop a skill & 60.00 & 54.33 & 59.40 & 32.60 & 35.64 & 34.12 & 4 & 30 \\
\hline RF72 & Insufficient skills & 55.82 & 55.82 & 60.30 & 31.16 & 33.66 & 32.41 & 5 & 38 \\
\hline RF73 & Lack of incentives and rewards for staff & 55.22 & 52.54 & 57.91 & 29.01 & 31.98 & 30.50 & 6 & 49 \\
\hline RF74 & Failure to comply with safety instructions & 53.13 & 52.84 & 55.22 & 28.07 & 29.34 & 28.71 & 7 & 55 \\
\hline RF75 & Lack of supervision and planning for work tasks & 51.05 & 51.64 & 57.61 & 26.36 & 29.41 & 27.88 & 8 & 60 \\
\hline RF76 & Unclear work instruction & 47.16 & 48.36 & 53.73 & 22.81 & 25.34 & 24.07 & 9 & 77 \\
\hline RF77 & Overload/extra work & 47.16 & 46.57 & 51.34 & 21.96 & 24.22 & 23.09 & 10 & 80 \\
\hline
\end{tabular}


top three significant factors are: "Shortage of skilled labours required to complete work tasks" and ranked 15th among the overall rework factors with T.I.I.R.I $=37.88 \%$. This result confirms several previous studies' findings, which ranked that as a significant factor in the first position in this group, such as Mahamid (2016), Jarkas (2015), and Ajayi and Oyeyipo (2015). The second factor was "Poor workmanship" and ranked as 21 th with T.I.I.R.I $=36.65 \%$. This result aligns with Jarkas (2015). Nevertheless, this did not come a very compatible with Ajayi and Oyeyipo (2015) who ranked that as a significant factor in the third position. Additionally, the third factor was "Reallocation Iturnover of the staff to another site" and ranked as 27th with T.I.I.R.I $=35.45 \%$. This result is similar to other studies by Ajayi and Oyeyipo (2015), Eze et al. (2018a), and Mahamid (2016).

In the Egyptian construction community, there is no construction industry sector free from defects attributed to labours. Indeed, the main reason for that is due to the lack of interest and considerations of the construction companies for this fundamental category in the project, since many contractors involve low-paid workers to maximise their profit, without considering of labours skills, in which turn can negatively affect the performance of construction projects.

\subsection{Material and equipment related factors}

The material and equipment related-factors are considered as the critical reasons for construction rework in other countries (Fayek et al., 2003; Enshassi et al., 2017; Josephson et al., 2002). In Sweden, for example, the material and equipment have been contributed to about $20 \%$ of the total rework cost (Josephson et al., 2002) and 14.81\% as another study carried by Fayek et al. (2003) in Canada.

This group is comprised of six rework causes, as shown in Table 12. According to analysis results, the first factor and the most critical one among this group was "Lack of materials in a site when needed" and ranked as 16th from overall rework causes with T.I.I.R.I $=37.60 \%$. This result is supporting the findings of Enshassi et al. (2010), who indicated that the lack of construction materials was a critical factor for many of the variation orders in the Gaza Strip. Thus, it leads to omitting some activities, replacing materials, and change of construction procedures. While the second important factor was "Inappropriate delivery timing of the materials and equipment by the supplier" and ranked as 47 th among all rework causes with T.I.I.R.I = $30.53 \%$. This result corresponds to the study conducted by Enshassi et al. (2017), which ranked the untimely deliveries as 52nd position. Besides, "Use poor quality materials" was the third rework cause in this group and ranked as 59th. This result not consistent with various prior studies, such as Mahamid (2016) in Palestine, Ye et al. (2014) in China, which ranked this factor in the third position as a significant rework cause of construction projects.

\subsection{External related factors}

Table 13 listed the rank of the four factors related to the external group causing rework in the Egyptian construction industry based on their impacts. According to the survey results, the two most influential factors are: the first was "Country's economic situation (currency exchange, inflation)", and came as the 1st position among all of 87 rework factors with T.I.I.R.I $=68.00 \%$, this attributed to the change in the currency exchange after the decision by the Central Bank of Egypt to float the Egyptian pound against other currencies. Hence, this factor has had a significant impact on the cost and duration of all Egyptian construction projects, which increased the price of materials dramatically, labour wages, equipment rates. Thus, forcing the concerned stakeholders to take several significant changes (for example, change in design, specifications, or Material). Accordingly, these caused major rework activities with an extreme impact on projects' cost and duration. However, this result does not conformity other studies of Enshassi et al. (2017) and Eze et al. (2018a) whose demonstrated that the economic situation as an insignificant factor of rework.

The second influential factor was "Change of laws and government decisions that initiated many changes, such as (design change)" and ranked as 17th amongst all of the rework causes with T.I.I.R.I $=37.40 \%$. Chang et al. (2011) supported this result when explained that the change of laws and government decisions is one reason for design change during construction. However, it did not substantiate by anther studies, such as Ye et al. (2014), who ranked this as an insignificant rework factor in China.

Table 12. Ranking the causes and impact of rework factors related to the materials and equipment

\begin{tabular}{|c|c|c|c|c|c|c|c|c|c|}
\hline Code & Factors cause the rework & $\begin{array}{l}\text { F.I } \\
(\%)\end{array}$ & $\begin{array}{c}\text { S.I on } \\
\text { cost }(\%)\end{array}$ & $\begin{array}{c}\text { S.I on } \\
\text { time }(\%)\end{array}$ & $\begin{array}{l}\text { I.I.R.C.I } \\
(\%)\end{array}$ & $\begin{array}{l}\text { I.I.R.T.I } \\
\quad(\%)\end{array}$ & $\begin{array}{c}\text { T.I.I.R.I } \\
(\%)\end{array}$ & $\begin{array}{c}\text { Group } \\
\text { rank }\end{array}$ & $\begin{array}{c}\text { Overall } \\
\text { rank }\end{array}$ \\
\hline RF78 & Lack of materials in a site when needed & 59.70 & 58.51 & 67.46 & 34.93 & 40.28 & 37.60 & 1 & 16 \\
\hline RF79 & $\begin{array}{l}\text { Inappropriate delivery timing of the } \\
\text { materials and equipment by the supplier }\end{array}$ & 53.13 & 54.33 & 60.60 & 28.87 & 32.20 & 30.53 & 2 & 47 \\
\hline RF80 & Use poor quality materials & 50.15 & 54.33 & 57.91 & 27.24 & 29.04 & 28.14 & 3 & 59 \\
\hline RF81 & Use defective/unadvanced equipment & 49.25 & 54.63 & 57.02 & 26.91 & 28.08 & 27.49 & 4 & 63 \\
\hline RF82 & Non-conformity to specifications & 49.85 & 52.24 & 55.52 & 26.04 & 27.68 & 26.86 & 5 & 66 \\
\hline RF83 & $\begin{array}{l}\text { Poor supervision by the contractor for the } \\
\text { acceptance's materials/equipment }\end{array}$ & 50.15 & 49.25 & 51.94 & 24.70 & 26.05 & 25.37 & 6 & 72 \\
\hline
\end{tabular}


Table 13. Ranking the causes and impact of rework factors related to external

\begin{tabular}{|c|c|c|c|c|c|c|c|c|c|}
\hline Code & Factors cause the rework & F.I (\%) & $\begin{array}{l}\text { S.I on } \\
\text { cost }(\%)\end{array}$ & $\begin{array}{l}\text { S.I on } \\
\text { time }(\%)\end{array}$ & $\begin{array}{l}\text { I.I.R.C.I } \\
(\%)\end{array}$ & $\begin{array}{l}\text { I.I.R.T.I } \\
(\%)\end{array}$ & $\begin{array}{l}\text { T.I.I.R.I } \\
(\%)\end{array}$ & $\begin{array}{c}\text { Group } \\
\text { rank }\end{array}$ & $\begin{array}{l}\text { Overall } \\
\text { rank }\end{array}$ \\
\hline RF84 & $\begin{array}{l}\text { Country's economic situation (currency } \\
\text { exchange, inflation) }\end{array}$ & 81.19 & 85.97 & 85.67 & 69.80 & 69.56 & 69.68 & 1 & 1 \\
\hline RF85 & $\begin{array}{l}\text { Change of laws and government decisions } \\
\text { that initiated many changes, such as } \\
\text { (design change) }\end{array}$ & 57.61 & 64.78 & 65.08 & 37.32 & 37.49 & 37.40 & 2 & 17 \\
\hline RF86 & Impact of social and cultural factors & 51.64 & 45.97 & 50.75 & 23.74 & 26.21 & 24.97 & 3 & 73 \\
\hline RF87 & $\begin{array}{l}\text { Natural conditions, such as rain, heat, and } \\
\text { cold }\end{array}$ & 45.67 & 44.78 & 49.55 & 20.45 & 22.63 & 21.54 & 4 & 86 \\
\hline
\end{tabular}

\section{Comparison between top rework causes in Egypt and other selected countries}

After analysing and ranking the factors of rework according to the Total Importance Index of Rework Impact (T.I.I.R.I.\%), Figure 3 shows the top fifteen critical factors among 87 factors causing rework, which have the highest impact on the cost and time of the construction projects in Egypt.

To conduct a comparative study, ten certain studies were selected for seven developing countries: China, Malaysia, Nigeria, Qatar, Palestine, South Africa, India, and UAE. Hence, to be a fair comparison, it became necessary to analyse and rank by rework factors in these areas carefully. Accordingly, the number of rework factors have been calculated along with the rank of each factor and the technique used for this ranking for each mentioned country. Consequently, the countries with similar rework factors were synchronised with the top 15 critical factors of rework in the current study. This was to elicit the ranks of rework factors that match the crucial rework factors in the Egyptian construction industry, as shown in Appendix, Table A2.

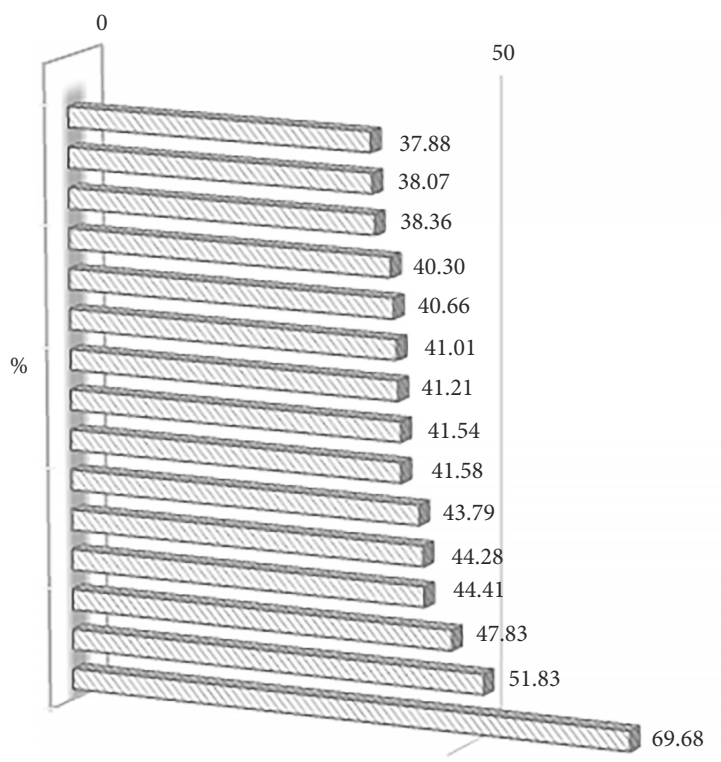

Furthermore, a detailed discussion has been conducted to compare the causes of rework; the results would be discussed in the following section.

In Egypt, "Country's economic situation (currency exchange, inflation)" came in 1st place, which was extremely significant, especially after the float of the Egyptian pound at the end of 2016. It has been ranked as a vital factor of rework in India, which ranked 9th. Raghuram and Nagavinothini (2016) demonstrated that Indian construction projects are suffering from design change due to financial reforms. On the contrary, the economic situation ranked as an insignificant factor for China, Malaysia, and Palestine, which reflects relative stability in the currency exchange and prices of building materials in these countries.

Also, "Schedule compression" ranked 2nd, which is also extremely critical. And, it has been ranked 4th as a significant factor for the Palestinian construction industry (Enshassi et al., 2017). This is due to the siege and political conditions in the region. On the other hand, it has also been ranked as an important factor in China and Qatar in 14th and 15th places, respectively.

Based on experts' opinions, it is noted that some factors such as "Design change due to its contradiction with

100
15. Shortage of skilied labours required to complete work tasks

14. Incomplete design at the time tender

13. Improper planning for the project activities

12.Weak communication/coordination with end-users

11.Design change at the client order or end-user

10. Changes initiated by client/end-user after work has been undertaken

9. Inefficient selection of the subcontractor

8. Lack of funding and cash flows

7. Weak planning of the project as (construction planning)

6. Change of plan or scope

5. Inadequate or weak feasibility study

4. Specifications change by the dient

3. Design change due to its contradiction with the utilities

2. Schedule compression

1. Country's economic situation (currency exchange, inflation)

Figure 3. The most critical rework factors in Egypt 
the utilities" (3rd rank), and "Inadequate or weak feasibility study" (5th rank) are the most influential factors of rework in Egypt, despite being of no concern for other selected countries, which ranked them as insignificant. This is attributed to a lack of funding for investigating site conditions, in addition to improper preparation of the feasibility study by the owners, and the lack of specialised consultancy offices to prepare it seriously.

Again, "Specifications change by the client" (4th rank) was an important factor for India, where it ranked in the 9th position, but it was not compatible with Nigeria (Aiyetan, 2013), where it ranked 47th. However, "Change of plan or scope" (6th rank) were ranked at 7th and 12th positions in China and Nigeria (Aiyetan, 2013), respectively, but they were not an adequate factor of rework for a residential building in Palestine (Mahamid, 2016), as they were ranked 17th. Additionally, "Weak planning of the project as (construction planning)" had the 5th rank in Nigeria (Aiyetan, 2013). This is in line with the views of Egyptian construction professionals, who ranked it in the 7th position.

From another side, the "Lack of funding and cash flows" (8th rank) and "Inefficient selection of the subcontractor" (9th rank) were the two most important factors related to the contractor and subcontractor in Egypt. These results correspond to Palestine, where they were ranked at the 15th (Enshassi et al., 2017) and 9th (Mahamid, 2016) positions, respectively. This convergence in results occurs because both countries have the same environment and cultural circumstances for construction projects.

The "Changes initiated by client/end-user after work has been undertaken" issue was a very significant factor in Qatar, where it ranked at the 1st position. Moreover, it was an influential factor of rework in Malaysia and India, where ranked it 9th and 5th, respectively. These results are considered acceptable in Egypt, which ranked it on the 10th. Nevertheless, the "Design change at the client order or end-user" (11th rank) matched with UAE, South Africa, Malaysia, and India, ranking it at 5th, 5th, 9th, and 14th, respectively. On the contrary, it was not a significant factor for Nigeria (Eze et al., 2018a), which came at 24th rank.

Among others, it was noted that the factors form that worry the construction makers in Egypt are "Weak communication/coordination with end-users" (12th rank), and it constituted $8.10 \%$ of the total cost of rework (Liu et al., 2020). This is in line with Malaysia, which ranked it on the 15th, and it was not an influential factor for China at 30th rank. "Improper planning for the project activities" was a significant factor of rework in Egypt as it ranked 13th, but this did not correspond with Qatar, where it ranked 24th. In the same way, the "incomplete design at the time tender" (14th rank) was a decisive factor in Qatar, where it ranked 3rd, and India, UAE, and South Africa at 6th rank. Also, it ranked 11th in both Palestine (Mahamid, 2016) and Nigeria (Eze et al., 2018a) and 12th in Malaysia. However, this was not disturbing for Palestine (Enshassi et al., 2017) and Nigeria (Aiyetan, 2013), where it ranked 17th and 48th, respectively.
Finally, "Shortage of skilled labours required to complete work tasks" has been ranked 15th, which is somewhat close to Palestine (Mahamid, 2016) and Nigeria (Eze et al., 2018a) that ranked it at 18th and 26th, respectively. On the other hand, this result is different from other countries such as UAE, India, and South Africa, where it was a critical factor in the 3rd position and ranked 5th for the Qatar projects. This may be attributed to the lack of skilled foreign labourers in these countries.

\section{Comparison of the rework groups rank with previous studies}

This section summarizes the rank of the ten rework categories in Egypt according to the average T.I.I.R.I(\%) and their percentages, as shown in Table 14. Besides comparing them with the results of 24 previous studies, as illustrated in Figure 4, which shows the contribution rates for the rework factors groups based on their frequencies in the 24 research studies. Hence, the five most influential groups in the Egyptian construction industry are discussed to compare their rank with corresponding groups of the previous studies, as follows.

Table 14. The rank of each rework group

\begin{tabular}{|l|c|c|c|}
\hline \multicolumn{1}{|c|}{ Groups } & $\begin{array}{c}\text { Average } \\
\text { T.I.I.R.I }(\%)\end{array}$ & Percentage & Rank \\
\hline External related factors & 38.40 & $11.94 \%$ & 1 \\
\hline Client related factors & 36.56 & $11.37 \%$ & 2 \\
\hline Construction related factors & 33.49 & $10.42 \%$ & 3 \\
\hline Design related factors & 32.76 & $10.19 \%$ & 4 \\
\hline $\begin{array}{l}\text { Contractor and } \\
\text { Subcontractor related factors }\end{array}$ & 32.75 & $10.19 \%$ & 4 \\
\hline Supervisory related factors & 31.58 & $9.82 \%$ & 5 \\
\hline Labour related factors & 31.08 & $9.67 \%$ & 6 \\
\hline $\begin{array}{l}\text { Material and Equipment } \\
\text { related factors }\end{array}$ & 29.33 & $9.12 \%$ & 7 \\
\hline Site related factors & 27.98 & $8.70 \%$ & 8 \\
\hline Contract related factors & 27.55 & $8.57 \%$ & 9 \\
\hline
\end{tabular}

The external related factors have been ranked as the first significant group with the average T.I.I.R.I $=38.40 \%$ and accounting for $11.94 \%$ among all rework groups. This result does not agree with the previous studies, which ranked it ninth, as accounting for $6.07 \%$ among all of the rework groups. The main reason for the fact occupies of the external related factors for this advanced rank is due to the economic changes over the last three years which negatively affected the performance of the Egyptian construction projects, such as the high prices of building materials. The second most influential group was client-related factors that require clients in Egypt to consider these factors to minimise their occurrence and impact and thus improve project performance. This result is in line with previous studies, which ranked it third, as accounting for $12.71 \%$ of the total rework groups. 


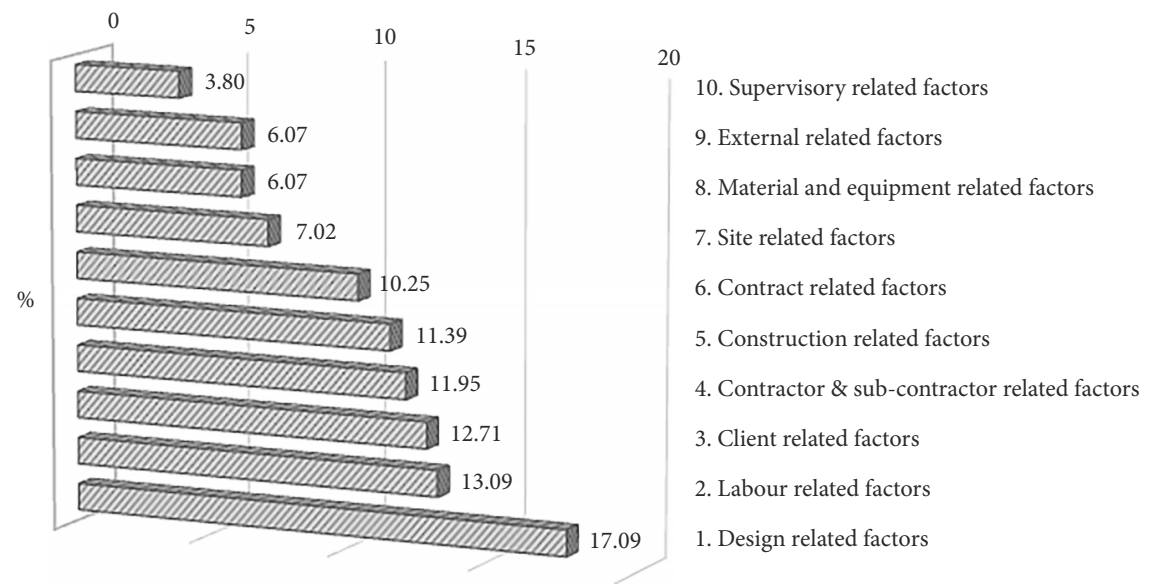

Figure 4. Percentages of rework factors groups in 24 previous studies

Also, the construction-related factors have been ranked as an influential group at third. This result matches with previous studies, which ranked it at fifth, representing $12.39 \%$ of total rework groups. Therefore, all stakeholders involved in the project should adequately plan the construction process, for example, developing a realistic schedule for project implementation. However, the fourth significant group is the design-related factors, which appeared concern source to the prior researchers, where they were ranked first and representing for $17.65 \%$ of all rework groups. This result indicates a lack of interest in the design process by the concerned parties involved in Egyptian construction projects.

At last, the fifth significant group was the contractor and subcontractor related factors, where it ranked as fourth. This finding is consistent with previous studies, which ranked it also fourth and accounting for $11.95 \%$ of the total rework groups. Hence, this category requires more attention by the owners, for example, the qualified contractors with considerable experience should be selected according to project type and complexity, which has a significant impact on the success of the project and minimising the rework.

\section{Conclusions and recommendations}

The study stated objectives are to identify the key causes of rework and measure the extent of their impact on the time and cost of Egyptian construction projects, as well as knowing the current results position against previous studies in other countries. Hence, to achieve the desired purpose of this paper, an extensive review of 24 prior studies was conducted to uncover ambiguity about the nature of rework causal. Accordingly, a total of 87 the rework causes have been identified and categorised them into ten groups related to, client, contractors and subcontractor, contract, design, supervisory, site, construction, material and equipment, labours, and external. Later, a questionnaire survey was conducted of 67 construction professionals in Cairo City to provide their opinions and perceptions regarding the importance of rework factors by completing their responses to the interview questionnaire. The results indicated that all of the participants are agreed that country's economic situation (currency exchange, inflation), schedule compression, design change due to its contradiction with the utilities, specifications change by the client, and inadequate or weak feasibility study are top five causes for rework in Egypt, which have the greatest impacts on projects performance. Therefore, those rework factors require more attention by both of the government agencies and the private sector. These results are justified in Egypt, based on surveyed experts' opinion whose attributed this, for example to the lack of analytical studies of the building market and the prices of construction materials that are updated continuously, and which will reduce the change orders of the construction projects tremendously. Additionally, a failure to take into account the site conditions before preparation the design schemes, which is due to insufficient prior site verification by the designer. Notwithstanding, according to 24 previous studies, the five most frequent of rework factors were the incomplete design at the time of the tender, poor communication of client with the contractor/design consultant, insufficient labour skills, the lack of sufficient client knowledge and experience in the design and construction process, and weak of quality considerations by contractor and subcontractor, which not matches the top five critical factors in Egypt.

On the other hand, the survey results indicated that the most dominant rework groups, which are those related to, external, client, construction, design, and contractor and subcontractor, respectively. The rank of these groups corresponds to the twenty-four previous studies rank, except for the external-related factors due to specified economic reasons.

In fact, the causes of rework in the construction industry are different from country to others, depending on economic and cultural conditions and the extent development of this industry. To demonstrated this, a comparative study was conducted to match the fifteen most important factors causing rework in Egypt with other developing countries which are China, Malaysia, Qatar, Palestine, South Africa, India, UAE, and Nigeria. The comparison 
results indicated that the main factors causing rework in Egypt have not agreed with those of countries regardabove, except for some individual cases.

In conclusion, the results of the current study can be considered valuable for international academics and researchers as it identified the largest number of rework causes, as well as it provides adequate knowledge about the common causes of rework and its impact in the Egyptian construction industry. Hence, the authors recommend the following measures to reduce the effects of rework and to improve projects performance in Egypt, which are:

- Both client and contractor must prepare a risk management plan of their own to avoid or reduce rework such as a risk of the currency exchange and inflation.

- Develop a new and appropriate approach for effective communication between project partner; client, consultant, contractor, and end-users to minimise changes that are requested during the project implementation.

- Involve professional coordinators to coordinate all work design panels, and coordinate the other requirements with external parties, which contributes to reducing the conflict as well as rework.

- Clients should prepare a meaningful and useful feasibility study, proper project planning, and solving the financial obligations of the contractor just in time.

- The initial investigations and tests of the site must be done at an early stage, to identify all obstacles, such as the utilities, soil problems to avoid future design and construction problems.

- The contractor shall establish a quality control system, to control the materials acceptance and construction work, which should be reviewed by the project's consultant as quality assurance, to avoid rework.

- The subcontractors should be selected according to an effective method based on their efficiency and skills basis.

\section{References}

Abdul-Rahman, H. (1995). The cost of non-conformance during a highway project: a case study. Construction Management and Economics, 13(1), 23-32. https://doi.org/10.1080/01446199500000004

Abeku, D. M., Ogunbode, E. B., Salihu, C., Maxwell, S. S., \& Kure, M. A. (2016). Projects management and the effect of rework on construction works: A case of selected projects in Abuja Metropolis, Nigeria. International Journal of Finance and Management in Practice, 4(1), 329-349.

Aiyetan, A. O. (2013). Causes of rework on building construction projects in Nigeria. https://hdl.handle.net/10520/EJC150372

Ajayi, O., \& Oyeyipo, O. (2015). Effect of rework on project performance in building project in Nigeria. International Journal of Engineering Research \& Technology, 4(2), 294-300.

Al-Reshaid, K., Kartam, N., Tewari, N., \& Al-Bader, H. (2005). A project control process in pre-construction phases: Focus on effective methodology. Engineering, Construction and Architectural Management, 12(4), 351-372.

https://doi.org/10.1108/09699980510608811
Alwi, S., Hampson, K. D., \& Mohamed, S. A. (1999). Investigation into the relationship between rework and site supervision in high rise building construction in Indonesia. In Proceedings of the International Conference on Construction Process Re-engineering '99 (pp. 189-195). Sydney, Australia.

Alwi, S., Keith, H., \& Sherif, M. (2001). Effect of quality supervision on rework in the Indonesian context. Asia Pacific Building and Construction Management Journal, 6, 2-6.

Arain, F. M., \& Pheng, L. S. (2006). Developers' views of potential causes of variation orders for institutional buildings in Singapore. Architectural Science Review, 49(1), 59-74. https://doi.org/10.3763/asre.2006.4908

Ashford, J. L. (1992). The management of quality in construction. $\mathrm{E}$ and $\mathrm{F}$ Spon.

Assaf, S. A., \& Al-Hejji, S. (2006). Causes of delay in large construction projects. International Journal of Project Management, 24(4), 349-357.

https://doi.org/10.1016/j.ijproman.2005.11.010

Barber, P., Graves, A., Hall, M., Sheath, D., \& Tomkins, C. (2000). Quality failure costs in civil engineering projects. International Journal of Quality \& Reliability Management, 17(4/5), 479-492. https://doi.org/10.1108/02656710010298544

Bekr, G. A. (2015). Causes of delay in public construction projects in Iraq. Jordan Journal of Civil Engineering, 9(2), 149-162.

Burati Jr, J. L., Farrington, J. J., \& Ledbetter, W. B. (1992). Causes of quality deviations in design and construction. Journal of Construction Engineering and Management, 118(1), 34-49. https://doi.org/10.1061/(ASCE)0733-9364(1992)118:1(34)

Chang, A. T., Shih, J. S., \& Choo, Y. S. (2011). Reasons and costs for design change during production. Journal of Engineering Design, 22(4), 275-289.

https://doi.org/10.1080/09544820903425218

Choudhry, R. M. (2016). Appointing the design consultant as supervision consultant on construction projects. Journal of Legal Affairs and Dispute Resolution in Engineering and Construction, 8(4), 04516005. https://doi.org/10.1061/(ASCE)LA.1943-4170.0000195

Construction Industry Institute (CII). (2001). The field rework index: Early warning for field rework and cost growth (RS 153-1, May). The University of Texas at Austin, Austin, Texas.

Dahanayake, B. M. Y., \& Ramachandra, T. (2016). Assessment on defects occurrence and rework costs in housing construction sector in Sri Lanka. http://dl.lib.mrt.ac.lk/handle/123/11715

Danso, H. (2014). Poor workmanship and lack of plant/equipment problems in the construction industry in Kumasi, Ghana. International Journal of Management Research, 2(3), 60-70.

Durdyev, S., Omarov, M., \& Ismail, S. (2017). Causes of delay in residential construction projects in Cambodia. Cogent Engineering, 4(1), 1291117. https://doi.org/10.1080/23311916.2017.1291117

El Hussein, K. (2014). Management of change-induced rework in a construction project [Doctoral dissertation]. The British University in Dubai (BUiD). http://bspace.buid.ac.ae/handle/1234/770

Enshassi, A., Arain, F., \& Al-Raee, S. (2010). Causes of variation orders in construction projects in the Gaza Strip. Journal of Civil Engineering and Management, 16(4), 540-551. https://doi.org/10.3846/jcem.2010.60

Enshassi, A., Sundermeier, M., \& Zeiter, M. A. (2017). Factors contributing to rework and their impact on construction projects performance. http://hdl.handle.net/20.500.12358/26569 
Eze, E. C., \& Idiake, J. E. (2018). Impact of rework on building project and organisation performance: A view of construction professionals in Nigeria. International Journal of Sustainable Construction Engineering and Technology, 9(1), 29-43. https://doi.org/10.30880/ijscet.2018.09.01.003

Eze, E. C., Idiake, J. E., \& Ganiyu, B. O. (2018a). Rework risks triggers in the Nigerian construction industry: a view of built environment professionals. Independent Journal of Management and Production, 9(2), 448-472.

https://doi.org/10.14807/ijmp.v9i2.729

Eze, E. C., Idiake, J. E., \& Ganiyu, B. O. (2018b). Analysis of rework risk triggers in the Nigerian construction industry. Organization, Technology and Management in Construction, 10(1), 1778-1793. https://doi.org/10.2478/otmcj-2018-0008

Fayek, A. R., Dissanayake, M., \& Campero, O. (2003). Measuring and classifying construction field rework: A pilot study (Research Report). Department of Civil and Environmental Engineering, University of Alberta.

Fayek, A. R., Dissanayake, M., \& Campero, O. (2004). Developing a standard methodology for measuring and classifying construction field rework. Canadian Journal of Civil Engineering, 31(6), 1077-1089. https://doi.org/10.1139/104-068

Fellows, R. R., \& Liu, A. (2008). Research methods for construction (3rd ed.). Wiley-Blackwell Science.

Feng, P. P., \& Tommelein, I. D. (2009). Causes of rework in California hospital design and permitting: Augmenting an existing taxonomy. In Annual Conference of the International Group for Lean Construction (pp. 407-416).

Forcada, N., Alvarez, A. P., Love, P. E., \& Edwards, D. J. (2016). Rework in urban renewal projects in Colombia. Journal of Infrastructure Systems, 23(2), 04016034.

https://doi.org/10.1061/(ASCE)IS.1943-555X.0000332

Gamil, Y., \& Abdul Rahman, I. (2020). Assessment of critical factors contributing to construction failure in Yemen. International Journal of Construction Management, 20(5), 429-436. https://doi.org/10.1080/15623599.2018.1484866

Gerges, M. (2015). Investigation into the labour factors affecting project performance within the Egyptian construction industry [Unpublished thesis]. Coventry University, Coventry.

Hassanein, A. A. G., \& El Nemr, W. (2008). Claims management in the Egyptian industrial construction sector: A contractor's perspective. Engineering, Construction and Architectural Management, 15(3), 246-259.

https://doi.org/10.1108/09699980810867406

Hwang, B. G., Shan, M., \& Tan, E. K. (2016). Investigating reworks in green building construction projects: Magnitude, influential factors, and solutions. International Journal of Environmental Research, 10(4), 499-510.

Hwang, B. G., Thomas, S. R., Haas, C. T., \& Caldas, C. H. (2009). Measuring the impact of rework on construction cost performance. Journal of Construction Engineering and Management, 135(3), 187-198.

https://doi.org/10.1061/(ASCE)0733-9364(2009)135:3(187)

Hwang, B. G., Zhao, X., \& Goh, K. J. (2014). Investigating the client-related rework in building projects: The case of Singapore. International Journal of Project Management, 32(4), 698-708. https://doi.org/10.1016/j.ijproman.2013.08.009

Investigate. (2017). Egypt sees construction boom with USD 348 bn active projects. http://invest-gate.me/news/egypt-sees-construction-boom-with-usd-348-bn-active-projects/

Jarkas, A. M. (2015). Rework in building construction: principle culprits and underlying causes. International Journal of Forensic Engineering, 2(4), 265-285.

https://doi.org/10.1504/IJFE.2015.075267
Josephson, P. E., Larsson, B., \& Li, H. (2002). Illustrative benchmarking rework and rework costs in Swedish construction industry. Journal of Management in Engineering, 18(2), 76-83. https://doi.org/10.1061/(ASCE)0742-597X(2002)18:2(76)

Kakitahi, J. M., Alinaitwe, H. M., Landin, A., \& Mone, S. J. (2016). Impact of construction-related rework on selected Ugandan public projects. Journal of Engineering, Design and Technology, 14(2), 238-251.

https://doi.org/10.1108/JEDT-02-2014-0006

Kakitahi, J. M., Landin, A., \& Alinaitwe, H. M. (2013). An exploratory study of rework causality in Uganda. Construction Innovation, 13(3), 266-280.

https://doi.org/10.1108/CI-Nov-2011-0051

Li, Y., \& Taylor, T. R. (2014). Modeling the impact of design rework on transportation infrastructure construction project performance. Journal of Construction Engineering and Management, 140(9), 04014044.

https://doi.org/10.1061/(ASCE)CO.1943-7862.0000878

Liao, L., \& Teo, E. A. L. (2017). Critical success factors for enhancing the building information modelling implementation in building projects in Singapore. Journal of Civil Engineering and Management, 23(8), 1029-1044.

https://doi.org/10.3846/13923730.2017.1374300

Liu, Q., Ye, G., Feng, Y., Wang, C., \& Peng, Y. (2020). Case-based insights into rework costs of residential building projects in China. International Journal of Construction Management, 20(4), 347-355.

https://doi.org/10.1080/15623599.2018.1484856

Long, N. D., Ogunlana, S., Quang, T., \& Lam, K. C. (2004). Large construction projects in developing countries: a case study from Vietnam. International Journal of Project Management, 22(7), 553-561.

https://doi.org/10.1016/j.ijproman.2004.03.004

Love, P. E. D. (2002a). Influence of project type and procurement method on rework costs in building construction projects. Journal of Construction Engineering and Management, 128(1), 18-29.

https://doi.org/10.1061/(ASCE)0733-9364(2002)128:1(18)

Love, P. E. D. (2002b). Auditing the indirect consequences of rework in construction: a case based approach. Managerial Auditing Journal, 17(3), 138-146.

https://doi.org/10.1108/02686900210419921

Love, P. E. D., \& Edwards, D. J. (2004). Forensic project management: The underlying causes of rework in construction projects. Civil Engineering and Environmental Systems, 21(3), 207-228. https://doi.org/10.1080/10286600412331295955

Love, P. E. D., \& Edwards, D. J. (2005). Calculating total rework costs in Australian construction projects. Civil Engineering and Environmental Systems, 22(1), 11-27.

https://doi.org/10.1080/10286600500049904

Love, P. E. D., \& Li, H. (2000). Quantifying the causes and costs of rework in construction. Construction Management and Economics, 18(4), 479-490.

https://doi.org/10.1080/01446190050024897

Love, P. E. D., \& Smith, J. (2018). Unpacking the ambiguity of rework in construction: making sense of the literature. Civil Engineering and Environmental Systems, 35(1-4), 180-203. https://doi.org/10.1080/10286608.2019.1577396

Love, P. E. D., Edwards, D. J., Smith, J., \& Walker, D. H. (2009). Divergence or congruence? A path model of rework for building and civil engineering projects. Journal of Performance of Constructed Facilities, 23(6), 480-488.

https://doi.org/10.1061/(ASCE)CF.1943-5509.0000054 
Love, P. E. D., Edwards, D. J., Watson, H., \& Davis, P. (2010). Rework in civil infrastructure projects: determination of cost predictors. Journal of Construction Engineering and Management, 136(3), 275-282.

https://doi.org/10.1061/(ASCE)CO.1943-7862.0000136

Love, P. E. D., Irani, Z., \& Edwards, D. J. (2004). A rework reduction model for construction projects. IEEE Transactions on Engineering Management, 51(4), 426-440. https://doi.org/10.1109/TEM.2004.835092

Love, P. E., Mandal, P., Smith, J., \& Li, H. (2000). Modelling the dynamics of design error induced rework in construction. Construction Management and Economics, 18(5), 567574. https://doi.org/10.1080/014461900407374

Mahamid, I. (2016). Analysis of rework in residential building projects in Palestine. Jordan Journal of Civil Engineering, 159, 197-208. https://doi.org/10.14525/JJCE.10.1.3536

Mastenbroek, Y. C. (2010). Reducing rework costs in construction projects [Bachelor's thesis]. University of Twente. http://purl.utwente.nl/essays/59691

McDonald, R. (2013). Root causes and consequential cost of rework - XL Catlin. North America Construction.

Miri, M., \& Khaksefidi, M. (2015). Cost management in construction projects: Rework and its effects. Mediterranean Journal of Social Sciences, 6(6 S6), 209-215.

https://doi.org/10.5901/mjss.2015.v6n6s6p209

Oyewobi, L. O., Ibironke, O. T., Ganiyu, B. O., \& Ola-Awo, A. W. (2011). Evaluating rework cost-A study of selected building projects in Niger State, Nigeria. Journal of Geography and Regional Planning, 4(3), 147-151. https://doi.org/10.5539/jsd.v4n4p175

Palaneeswaran, E. (2006). Reducing rework to enhance project performance levels. In Proceedings of the One Day Seminar on Recent Developments in Project Management in Hong Kong. http://www.civil.hku.hk/cicid/3_events/48/papers/5.pdf

Rachid, Z., Toufik, B., \& Mohammed, B. (2019). Causes of schedule delays in construction projects in Algeria. International Journal of Construction Management, 19(5), 371-381. https://doi.org/10.1080/15623599.2018.1435234

Raghuram, S., \& Nagavinothini, R. (2016). Investigation on the causes and adverse effects of reworks in construction projects and developing a rework reduction model to mitigate time and cost. https://www.semanticscholar.org/paper/Investigationon-the-Causes-and-Adverse-Effects-of-Raghuram-Nagavinothini/e6e4976f5038bd878b9769c82c951123037e016b

Shibnai, A., \& Salah, K. (2015). Time and cost overrun in construction projects in Egypt. https://www.academia.edu/36106334/ Time_and_Cost_Overrun_in_Construction_Projects_in_ Egypt

Simpeh, E. K. (2012). An analysis of the causes and impact of rework in construction projects [Doctoral dissertation]. Cape Peninsula University of Technology. http://hdl.handle.net/20.500.11838/1046

Tavakol, M., \& Dennick, R. (2011). Making sense of Cronbach's alpha. International Journal of Medical Education, 2, 53-55. https://doi.org/10.5116/ijme.4dfb.8dfd

Thomas, H. R., \& Napolitan, C. L. (1995). Quantitative effects of construction changes on labor productivity. Journal of Construction Engineering and Management, 121(3), 290-296. https://doi.org/10.1061/(ASCE)0733-9364(1995)121:3(290)
Trading Economics. (2019). Egypt GDP from construction. https://tradingeconomics.com/egypt/gdp-from-construction

UKTI Digital. (2016). Construction sector in Egypt. https://opentoexport.com/article/construction-sector-inegypt-1/

Wasfy, M. A. F. (2010). Severity and impact of rework, a case study of a residential commercial tower project in the Eastern Province-KSA. King Fahd University.

Xin, L., \& Rong, W. (2007). Survey research on relationship among service failures, service recovery and customer satisfaction. In 2007 International Conference on Management Science and Engineering (pp. 1121-1126). IEEE. https://doi.org/10.1109/ICMSE.2007.4421996

Yap, J. B. H., Abdul-Rahman, H., \& Wang, C. (2016). A conceptual framework for managing design changes in building construction. In The 4th International Building Control Conference 2016 (IBCC 2016), 66, 00021. EDP Sciences. https://doi.org/10.1051/matecconf/20166600021

Yap, J. B. H., Low, P. L., \& Wang, C. (2017). Rework in Malaysian building construction: Impacts, causes and potential solutions. Journal of Engineering, Design and Technology, 15(5), 591-618. https://doi.org/10.1108/JEDT-01-2017-0002

Ye, G., Jin, Z., Xia, B., \& Skitmore, M. (2014). Analyzing causes for reworks in construction projects in China. Journal of Management in Engineering, 31(6), 04014097. https://doi.org/10.1061/(ASCE)ME.1943-5479.0000347 


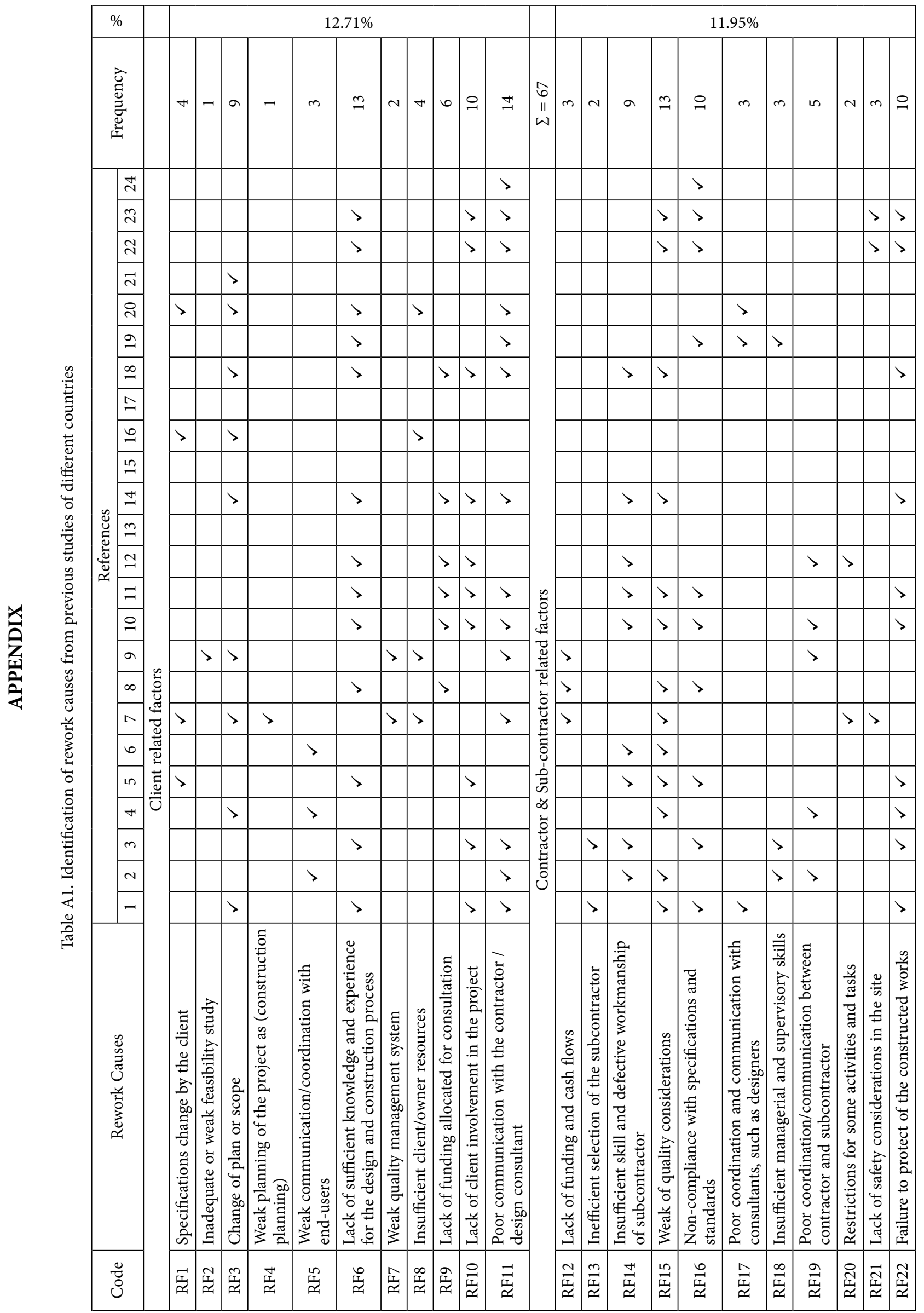




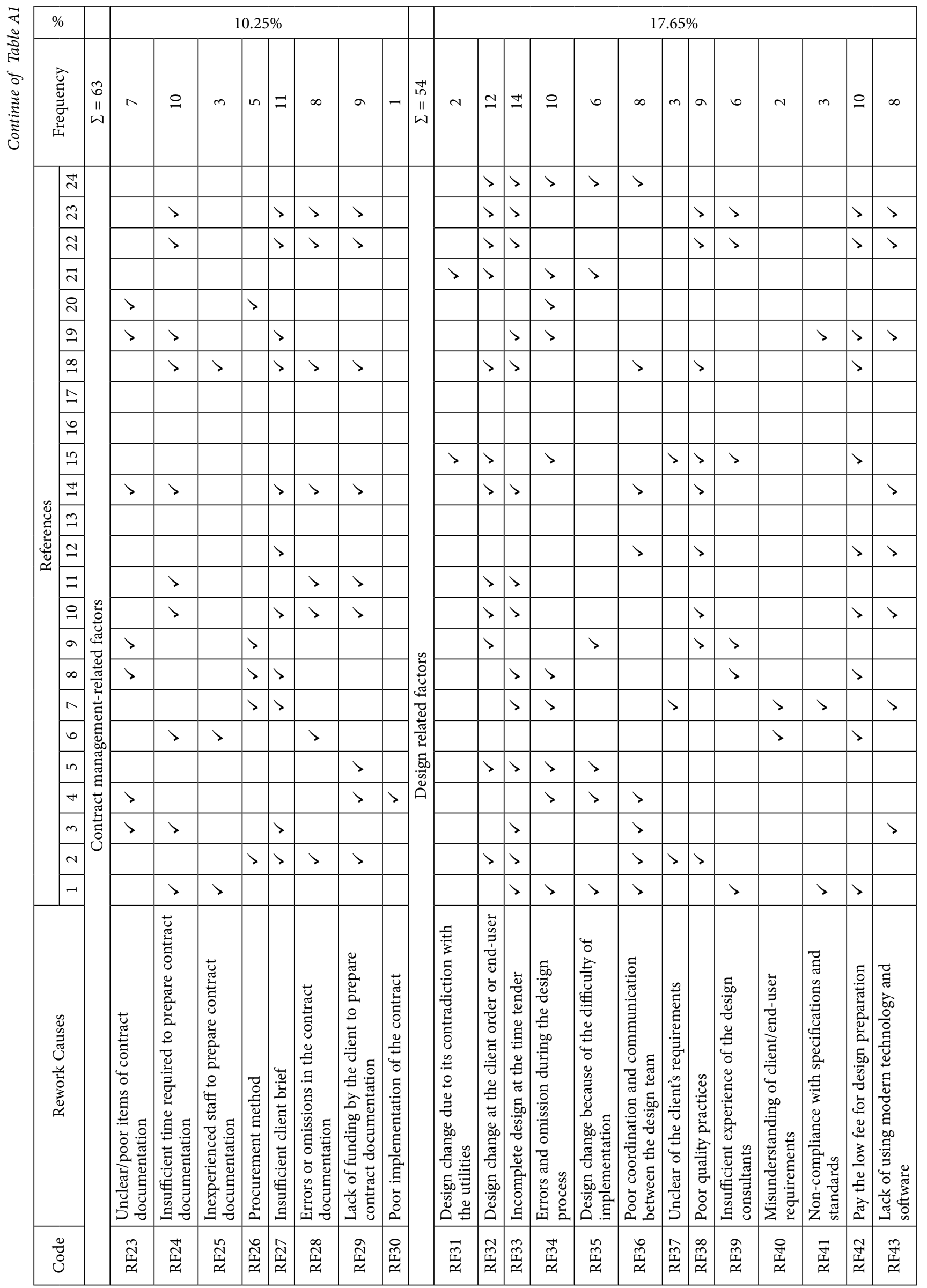




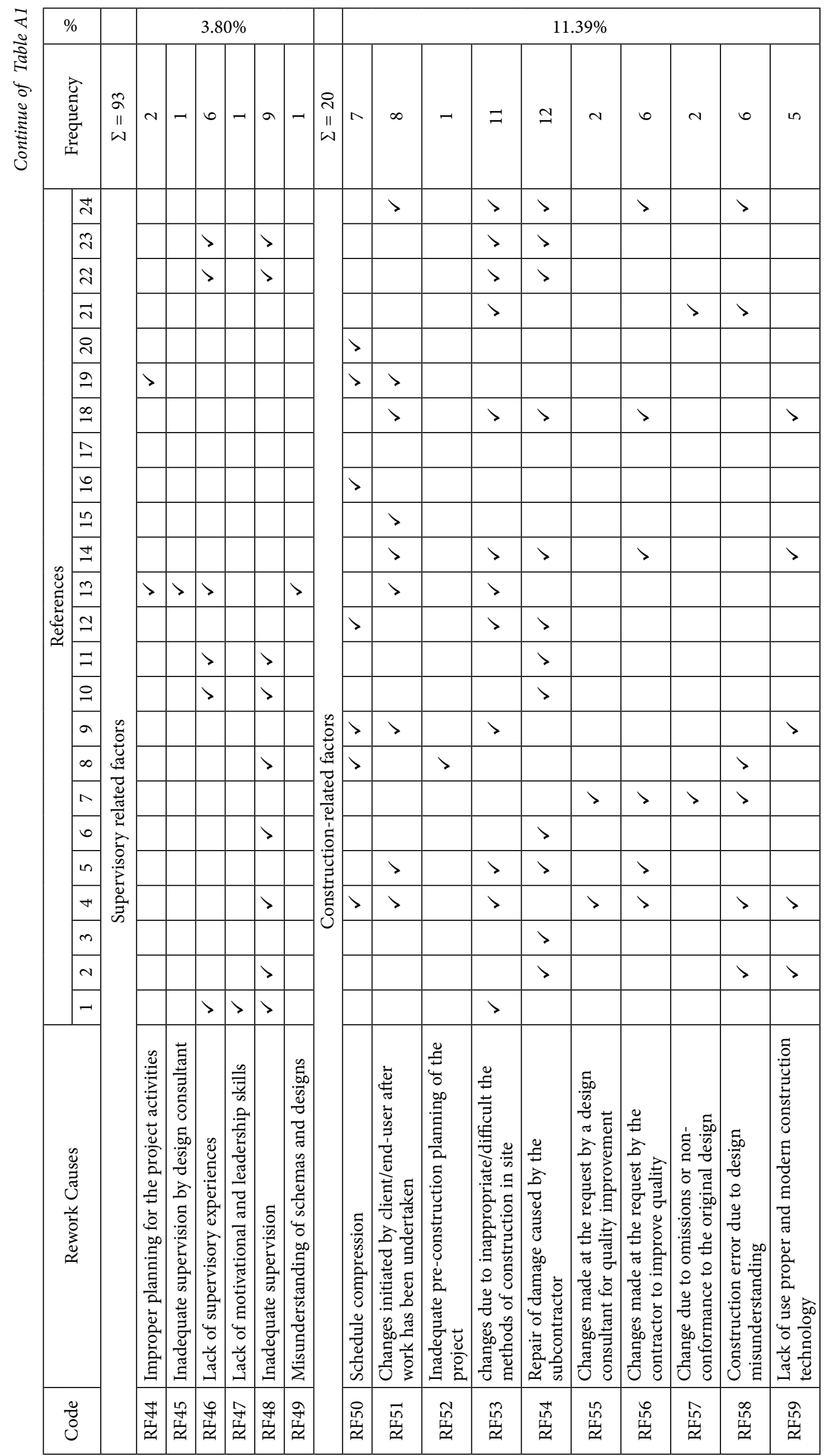




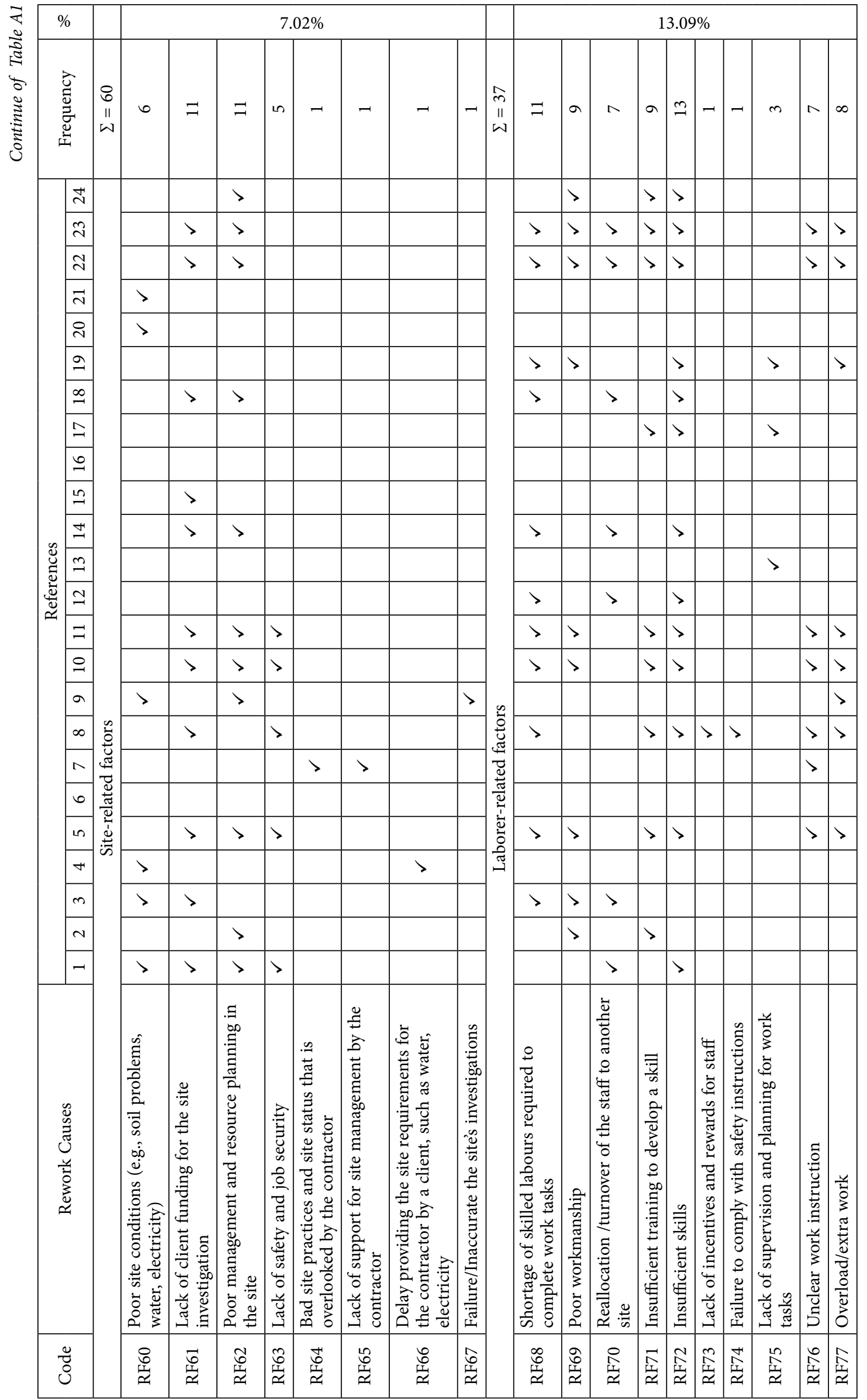




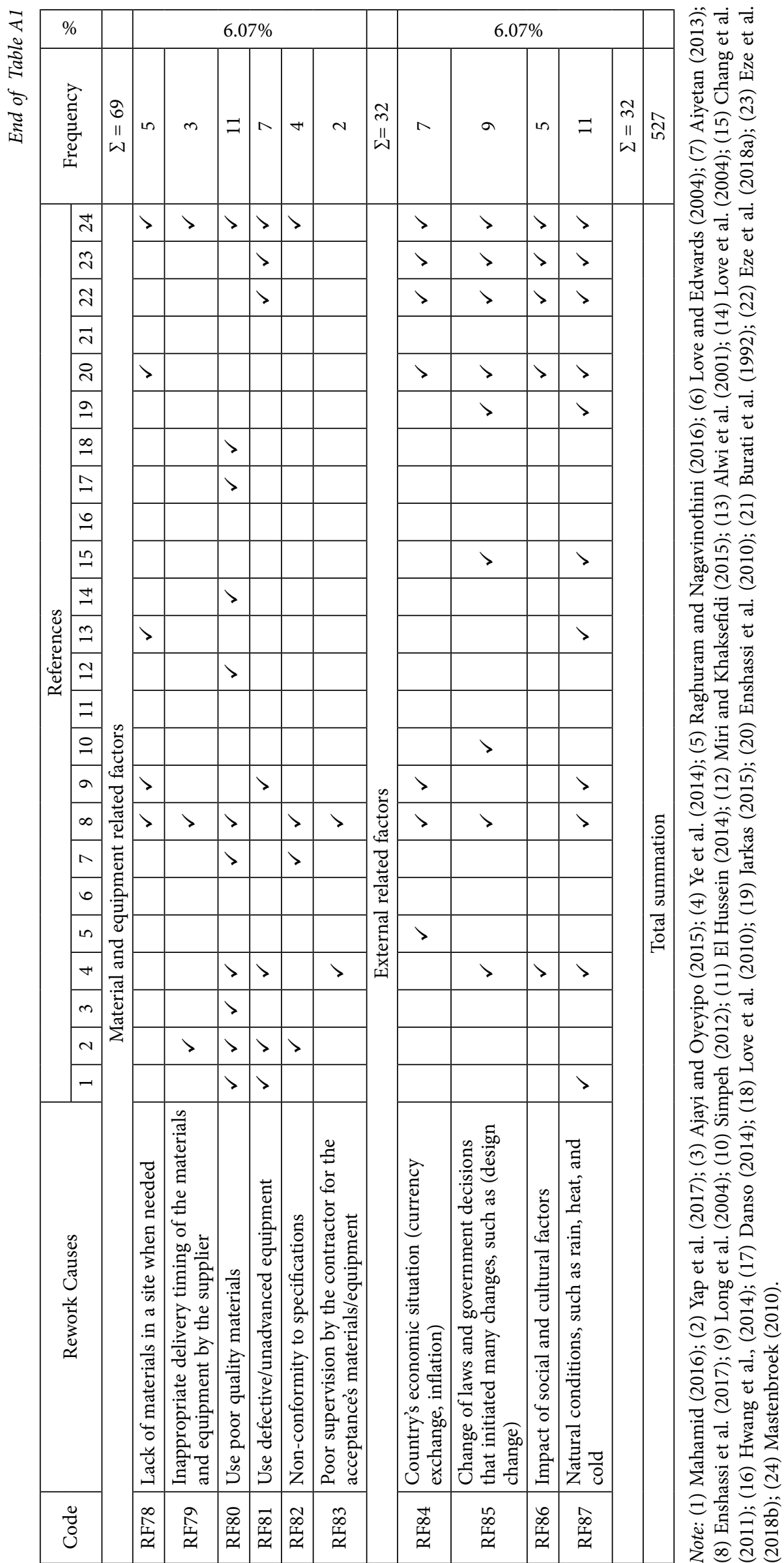




\begin{tabular}{|c|c|c|c|c|c|c|c|c|c|c|c|c|c|c|c|c|}
\hline \multirow{3}{*}{ 四急密 } & 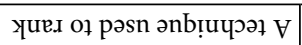 & \multicolumn{15}{|c|}{ 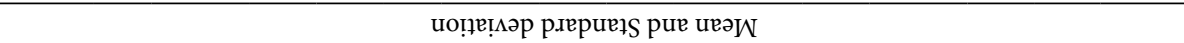 } \\
\hline & рәучеу & 1 & 1 & । & I & I & । & 1 & 1 & 1 & I & in & I & 1 & 6 & $m$ \\
\hline & s.оңәеј у.омәх јо 'оN & \multicolumn{15}{|c|}{ S.ołวeJ IE } \\
\hline \multirow{3}{*}{ 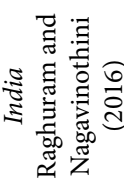 } & 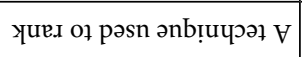 & \multicolumn{15}{|c|}{ ивәШ } \\
\hline & рәучеу & $a$ & 1 & । & $a$ & 1 & । & । & । & I & $\bullet$ & $\Xi$ & । & । & 6 & $m$ \\
\hline & 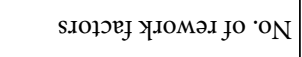 & \multicolumn{15}{|c|}{ S.Ołכe' 0t } \\
\hline \multirow{3}{*}{ 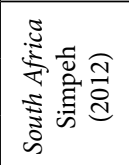 } & 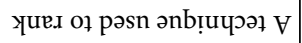 & \multicolumn{15}{|c|}{ 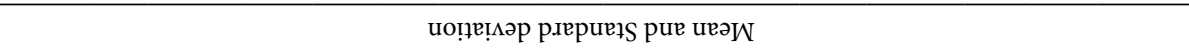 } \\
\hline & рәучеу & 1 & 1 & । & । & । & 1 & 1 & 1 & 1 & 1 & in & । & । & 6 & $m$ \\
\hline & 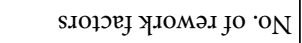 & \multicolumn{15}{|c|}{ S.IOłวE $8 \mathcal{E}$} \\
\hline \multirow{3}{*}{ 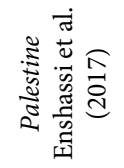 } & 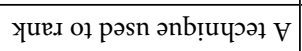 & \multicolumn{15}{|c|}{ 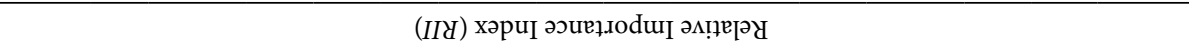 } \\
\hline & рәучеу & F & $H$ & । & । & 1 & । & । & $\stackrel{20}{2}$ & । & । & । & । & । & $\bumpeq$ & । \\
\hline & 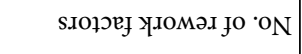 & \multicolumn{15}{|c|}{ S.Ołכe' $\angle S$} \\
\hline \multirow{3}{*}{ 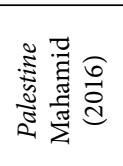 } & 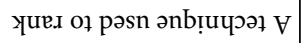 & \multicolumn{15}{|c|}{ (I’S) хәриі Кџ!ฺәнәS } \\
\hline & рәучеу & 1 & 1 & । & । & 1 & $\bumpeq$ & 1 & 1 & $a$ & । & । & 1 & । & $=$ & $\stackrel{\infty}{\sim}$ \\
\hline & 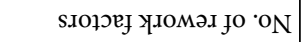 & \multicolumn{15}{|c|}{ SIOłJEJ ET } \\
\hline \multirow{3}{*}{ 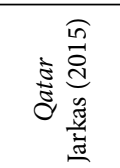 } & ұие. & \multicolumn{15}{|c|}{ 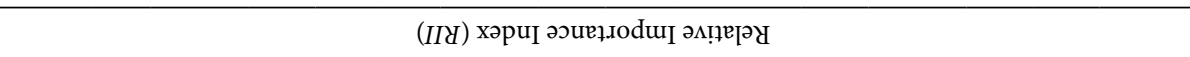 } \\
\hline & рәучеу & । & 20 & । & । & I & । & 1 & 1 & 1 & - & । & । & 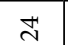 & $m$ & in \\
\hline & s.оұวеу у.омәх јо 'оN & \multicolumn{15}{|c|}{ 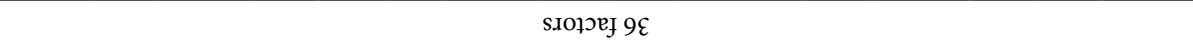 } \\
\hline \multirow{3}{*}{ 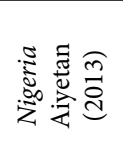 } & 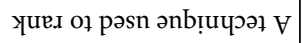 & \multicolumn{15}{|c|}{ чеәW } \\
\hline & рәучеу & । & 1 & । & 多 & । & $\simeq$ & in & । & । & । & । & । & । & $\stackrel{\infty}{+}$ & । \\
\hline & 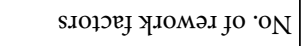 & \multicolumn{15}{|c|}{ S.OłวeJ I $L$} \\
\hline \multirow{3}{*}{ 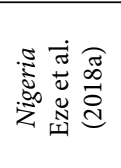 } & צนе. & \multicolumn{15}{|c|}{ uеәW } \\
\hline & рәуиеу & in & । & । & । & । & । & । & । & । & । & $\underset{d}{H}$ & । & । & $\exists$ & $\stackrel{N}{\sim}$ \\
\hline & 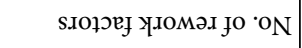 & & & & & & & & s.oło & 打 $\angle T$ & & & & & & \\
\hline & 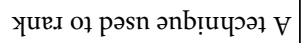 & & & & & & & иоп̣е!̣ıәр & рлерu & IRTS Pu & Iе чеәу & & & & & \\
\hline 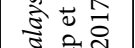 & рәуиеу & । & 1 & । & । & । & । & । & । & । & $a$ & $a$ & $\underline{n}$ & । & 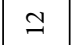 & । \\
\hline & 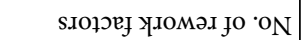 & & & & & & & & s.ołoe & 护 8I & & & & & & \\
\hline & 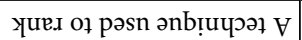 & & & & & & & 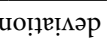 & pлepu & IETS Pu & Iе чеәW & & & & & \\
\hline ఏ む & рәучеу & i & $\Xi$ & । & । & । & $\wedge$ & । & । & 1 & । & । & ஓे & । & । & । \\
\hline & 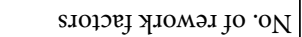 & & & & & & & & s.oło & ef $6 \varepsilon$ & & & & & & \\
\hline 昰 & צนе. & & & & & $\% I^{*}{ }^{*} T^{*}$ & {$[L)+$} & oeduI yII & IOMәY & јо хәр & uI әэuеł.jod & wi & & & & \\
\hline 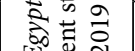 & pəyuey & - & v & $m$ & $H$ & in & 6 & $n$ & $\infty$ & $a$ & 음 & $=$ & $\simeq$ & $\underline{n}$ & $\exists$ & 20 \\
\hline$\vec{J}$ & s.оұวв у у.омәх јо 'оN & & & & & & & & S.IOłJe & 打 $\angle 8$ & & & & & & \\
\hline & 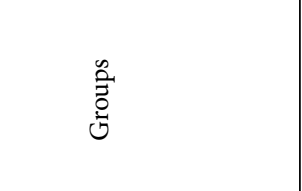 & 苞 & $\begin{array}{l}0 \\
\stackrel{0}{0} \\
\stackrel{0}{0} \\
0 \\
0\end{array}$ & 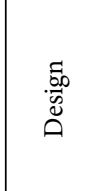 & 节 & 节 & 节 & 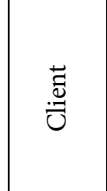 & 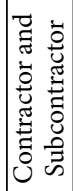 & 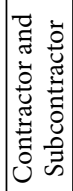 & 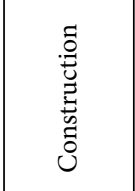 & 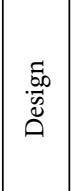 & 节 & 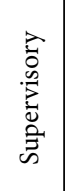 & 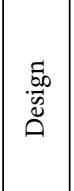 & 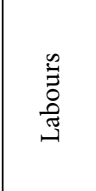 \\
\hline & 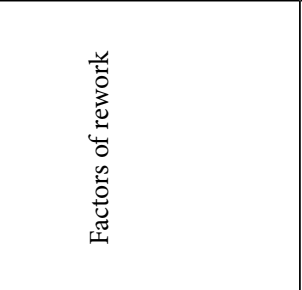 & 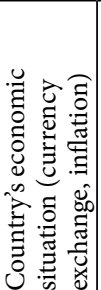 & 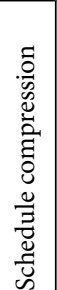 & 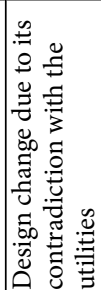 & 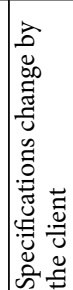 & 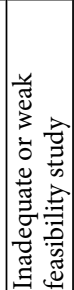 & 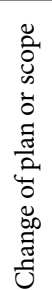 & 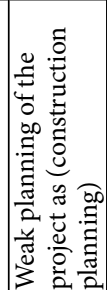 & 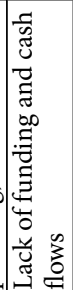 & 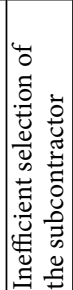 & 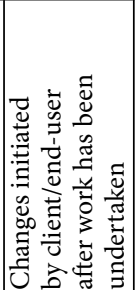 & 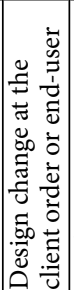 & 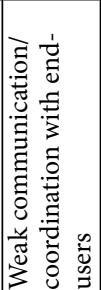 & 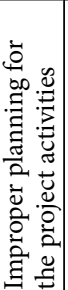 & 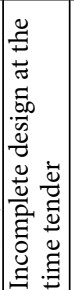 & 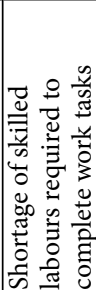 \\
\hline
\end{tabular}

